Article

\title{
Thermal Performance and Comfort Condition Analysis in a Vernacular Building with a Glazed Balcony
}

\author{
Jorge Fernandes ${ }^{1}{ }^{\mathbb{D}}$, Raphaele Malheiro ${ }^{1}$, Maria de Fátima Castro ${ }^{1}$, Helena Gervásio ${ }^{2}{ }^{\circledR}$, \\ Sandra Monteiro Silva ${ }^{1}$ (D) and Ricardo Mateus ${ }^{1, *(D)}$ \\ 1 Department of Civil Engineering, University of Minho, Campus de Azurém, 4800-058 Guimarães, Portugal; \\ jepfernandes@me.com (J.F.); raphamalheiro@gmail.com (R.M.); info@mfcastro.com (M.d.F.C.); \\ sms@civil.uminho.pt (S.M.S.) \\ 2 Institute for Sustainability and Innovation in Structural Engineering (ISISE), University of Coimbra, \\ University of Coimbra, Faculdade de Ciências e Tecnologia, Rua Luís Reis Santos, Pólo II, 3030-788 Coimbra, \\ Portugal; hger@dec.uc.pt \\ * Correspondence: ricardomateus@civil.uminho.pt
}

Received: 10 November 2019; Accepted: 22 January 2020; Published: 1 February 2020

check for updates

\begin{abstract}
The increase in global environmental problems requires more environmentally efficient construction. Vernacular passive strategies can play an important role in helping reducing energy use and $\mathrm{CO}_{2}$ emissions related to buildings. This paper studies the use of glazed balconies in the North of Portugal as a strategy to capture solar gains and reduce heat losses. The purpose is understanding thermal performance and comfort conditions provided by this passive heating strategy. The methodology includes objective (short and long-term monitoring), to evaluate the different parameters affecting thermal comfort and air quality, and subjective assessments to assess occupants' perception regarding thermal sensation. The results show that the use of glazed balconies as a passive heating strategy in a climate with cold winters is viable. During the mid-seasons, the rooms with balcony have adequate comfort conditions. In the heating season, it is possible to achieve comfort conditions in sunny days while in the cooling season there is a risk of overheating. Regarding indoor air quality, carbon dioxide concentrations were low, but the average radon concentration measured was high when the building was unoccupied, rapidly decreasing to acceptable values, during occupation periods when a minimum ventilation rate was promoted. Occupants' actions were essential to improving building behavior.
\end{abstract}

Keywords: glazed balcony; indoor comfort; passive strategies; thermal performance; vernacular architecture

\section{Introduction}

\subsection{Context}

The construction industry is one of the largest and most active sectors of the world economy. Regarding the importance of this sector and its influence on sustainable development issues, several organizations set different goals to achieve more efficient construction. For example, the European Union (EU) is committed to developing a sustainable, competitive, secure, and decarbonized energy system setting a goal for reducing carbon dioxide $\left(\mathrm{CO}_{2}\right)$ emissions by at least $40 \%$ by 2030 and by 80-95\% until 2050, compared to 1990 values [1,2]. In parallel, it is intended to increase the proportion of renewable energy consumed and to improve Europe's energy security, competitiveness, and sustainability [3]. 
According to Directive (EU) 2018/844, it is essential to ensure that measures to improve the energy performance of buildings do not focus only on the building envelope. It should also include all relevant elements and technical systems in a building, such as passive elements that can contribute to reducing energy needs for heating or cooling, as well as energy use for lighting and ventilation, and hence improve thermal and visual comfort [3].

Therefore, one of the ways to improve the sustainability of buildings is to reduce the importance of active systems and give higher priority to architectural form and passive systems [4-6]. Passer et al. [6] demonstrated that technical equipment has a significant influence on the life cycle environmental impacts of buildings. These authors also concluded that, on a life cycle assessment approach, passive buildings have the lowest impacts associated with mechanical equipment, mainly because they have reduced needs for mechanical ventilation and air conditioning systems [6]. The introduction of passive strategies in buildings from the design stage reduces the amount and the need for these types of systems [5].

In the context of passive techniques aiming to reduce energy needs, it is important to analyze vernacular architecture to understand the way vernacular buildings were shaped to suit local climate constraints. Additionally, the strategies that are now the basis of sustainable construction derive from aspects and characteristics of this type of architecture [7]. In these construction projects, strategies used to mitigate the effects of climate and ensure thermal comfort conditions are usually passive in operation, low in technology, and do not depend on fossil energy to operate, making them particularly suitable for contemporary building applications, mainly in the design of passive buildings. For this reason, vernacular architecture continues to be the subject of several studies whose findings seek to contribute to the development of a more sustainable built environment. Although these studies have been taking part around the world, they adopted similar methodologies and reported similar conclusions and limitations. These conclusions highlight that the use of vernacular techniques and local materials in the design of buildings, developed on the basis of the need for adaptation to a specific territory and climate, will contribute to the reduction of waste, energy use, and consequently carbon emissions, among other environmental impacts [8-12].

Additionally, the study and valorization of the vernacular buildings and the inherent knowledge will contribute not only to its preservation but also to the dynamization of local economies [13].

\subsection{Vernacular Strategies and the Built Environment}

In the past, due to the lack of active systems, buildings were built using passive strategies to reduce thermal discomfort. These strategies were based on available endogenous resources and design principles arising from local geographical characteristics [10,14]: insolation; orientation; topography; shape; and materials, among others.

The relationship between the built and the natural environments, well described by the mythological concept of Genius Loci, is of prime importance in the design of buildings and their thermal performance. As an example, it was not random how the North African houses and the North European houses were designed, or, in the Portuguese context, the differences between northern and southern interior residential buildings.

Regarding the thermal performance of vernacular buildings, several quantitative studies conducted in different parts of the world have shown that these buildings achieve acceptable levels of thermal comfort throughout most of the year using only passive strategies, in some cases with indoor temperature remaining stable [7,15-19]. In some of these studies, vernacular buildings performed better than contemporary buildings, although several of the building solutions adopted do not meet current thermal regulation requirements. These results support the idea that passive strategies are, in many cases, feasible for application in contemporary buildings and can contribute to the reduction of energy requirements for air-conditioning. The adequate response of vernacular solutions to climate constraints reveals the importance of local specificities for contemporary construction, in terms of sustainability and energy efficiency $[11,12,20,21]$. 
In this context, some authors, like Ascione, et al. [22] defend that the building orientation and its passive design can positively affect the energy and environmental performance of buildings. For instance, glazed balconies act as a sunspace (Figure 1) and are a vernacular design solution that can contribute to the thermal performance of buildings during the heating season, since the sunspace heats the adjacent rooms, not compromising the thermal behavior of the building during summer [23]. This technique also has great potential to be used in contemporary buildings to improve energy efficiency, as shown by the case of the rehabilitation of the residential complex of Dornbirn, in Austria. The option of introducing this type of solution in the south-facing facades has increased the floor area of the dwellings and significantly reduced the heating energy bill [24]. The operation of these balconies as a buffer space allows the simultaneous capture and trapping of solar gains and reduction of heat losses. By being physically separated from the interior spaces of the dwellings, in situations where heat gain is undesirable, the balcony space can act as a shading device and promotes natural ventilation [24].
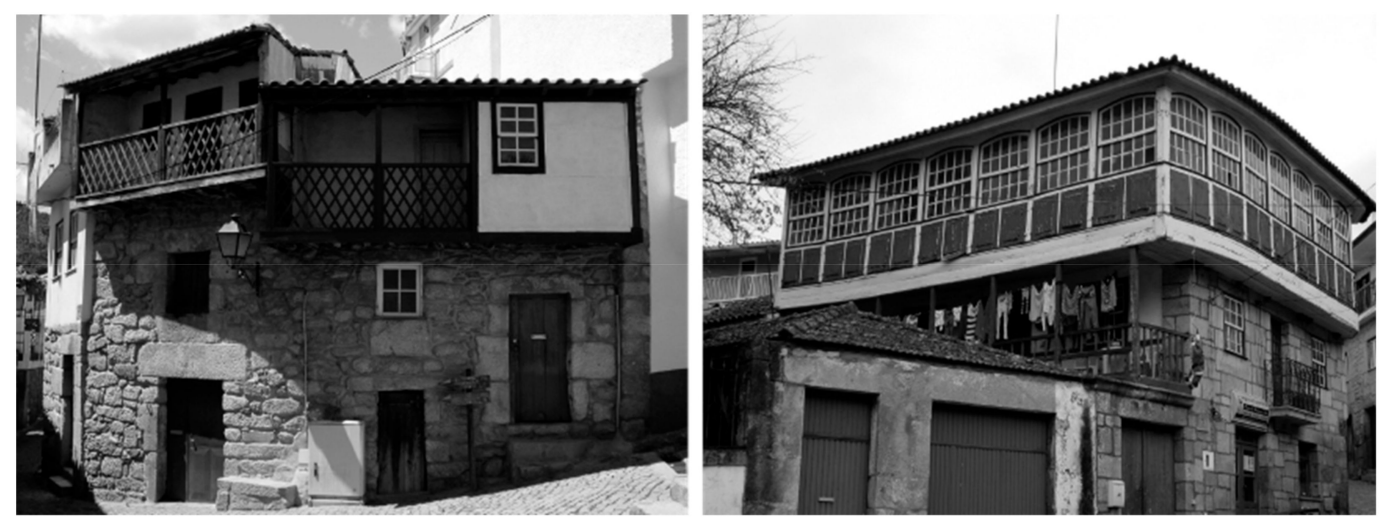

Figure 1. Balconies in the vernacular architecture of Beira Alta, Portugal.

The vernacular architecture strategies can contribute to improving the energy efficiency of buildings, whereas the local specificities should assume particular relevance. At a time of achieving high-performance buildings, defining the future of architecture and construction should seek to integrate tradition with modernity, at a crossroad that unites the best of today's technological potentialities with traditional materials and techniques [4].

\subsection{Aim of This Research}

The study of Portuguese vernacular architecture based on in situ measurements that allow a comprehensive demonstration of the effects of vernacular passive strategies on thermal performance is still lacking. In Portugal, there are only a few quantitative studies [25-28] focusing on passive strategies and their contribution to the thermal performance of buildings.

Analyzing the state-of-art for the specific context of vernacular buildings with glazed balconies, it is possible to verify that there are no quantitative studies developed so far on their thermal performance. Thus, this study aims to contribute to the development of this field of research by analyzing the thermal performance of a vernacular building with a glazed balcony, located in Northern Portugal (region of Beira Alta), considering the thermal comfort standards, and analyzing how the glazed balcony technique suit the local conditions. To fulfil this goal, the study consists of assessing the hygrothermal parameters that characterise the indoor thermal environment and that affect the occupants' thermal comfort conditions.

The number of existing vernacular buildings with glazed balconies identified in the Survey on Portuguese Popular Architecture [29] is decreasing, and it is becoming increasingly difficult to find this type of building in good condition. Therefore, this study intends to demonstrate the potential of this passive technique on improving the indoor environmental quality and reducing the energy needs 
of buildings. Presenting quantitative data about the thermal performance will contribute to a better understanding of this type of buildings and about the contribution of glazed balconies in maintaining indoor temperatures within the comfort range. This research will also contribute to the preservation of this type of building and their related knowledge.

\section{Materials and Methods}

To assess indoor thermal performance, in situ assessments were divided into short and long-term monitoring. In these assessments, the hygrothermal parameters that characterize the indoor thermal environment and that affect the body/environment heat exchange (air temperature, relative humidity, mean radiant temperature, and air velocity) were measured. The measurements were carried out from the autumn of 2014 to the summer of 2015.

\subsection{Short-Term Monitoring}

Short-term monitoring was carried out at least one day per season and consisted of objective measurements and subjective evaluation:

- Objective measurements had the purpose of quantitatively assess the thermal comfort conditions in a room using a thermal microclimate station (model Delta OHM 32.1) that measures air temperature, relative humidity, mean radiant temperature, and air velocity (Table 1), in compliance with standards ISO 7726 [30], ISO 7730 [31], and ASHRAE 55 [32]. The location of the equipment is chosen according to occupants' distribution in the room and in the rooms where occupants stay for more extended periods. The measurements were performed considering that the occupants were seated, as recommended in ASHRAE 55 [32]. The data recorded in these measurements was used to determine the operative temperature (the analysis procedure is explained below in this section).

- Subjective evaluation was carried out to assess the occupants' perceived indoor environment quality, using surveys. The case study building is occupied by two persons, which comfort level was surveyed. The survey was based in the "Thermal Environment Survey" from ASHRAE 55 [32] and was used to determine occupants' satisfaction according to ASHRAE thermal sensation scale.

Table 1. Location and characteristics of measurement equipment used.

\begin{tabular}{|c|c|c|}
\hline Equipment & $\begin{array}{l}\text { Specifications, Measurement Range and } \\
\text { Accuracy }\end{array}$ & Location \\
\hline $\begin{array}{l}\text { Thermal microclimate station (model Delta OHM } \\
\text { 32.1) }\end{array}$ & $\begin{array}{l}\text { Probes installed: } \\
\text { 1. Globe temperature probe } \varnothing 150 \mathrm{~mm} \text { (range } \\
\text { from }-10 \text { to } 100^{\circ} \mathrm{C} \text { ); } \\
\text { 2. Omnidirectional hot-wire probe for wind } \\
\text { speed measurement (range from } 0 \text { to } 5 \mathrm{~m} / \mathrm{s} \text { ); } \\
\text { 3. Combined temperature and relative } \\
\text { humidity probe (range from }-10 \text { to } 80{ }^{\circ} \mathrm{C} \text { and } \\
5-98 \% \mathrm{RH} \text { ); } \\
\text { 4. Two-sensor probe for measuring natural } \\
\text { wet bulb temperature and dry bulb } \\
\text { temperature (range from } 4 \text { to } 80^{\circ} \mathrm{C} \text { ). }\end{array}$ & $\begin{array}{c}\text { Living room/kitchen } \\
\text { and bedroom with } \\
\text { balcony }\end{array}$ \\
\hline
\end{tabular}


Table 1. Cont

\begin{tabular}{|c|c|c|}
\hline Equipment & $\begin{array}{l}\text { Specifications, Measurement Range and } \\
\text { Accuracy }\end{array}$ & Location \\
\hline $\begin{array}{l}\text { Thermo-hygrometer and datalogger (Klimalogg Pro, } \\
\text { TFA 30.3039.IT) + Wireless thermo-hygrometer } \\
\text { transmitters (model TFA 30.3180.IT) connected to the } \\
\text { datalogger }\end{array}$ & $\begin{array}{l}\text { Datalogger: } \\
\text { - } \quad \text { Temperature accuracy of } \pm 1{ }^{\circ} \mathrm{C} \text { and a } \\
\text { measuring range between } 0 \text { and } 50{ }^{\circ} \mathrm{C} \\
\text { with } 0.1^{\circ} \mathrm{C} \text { resolution; } \\
\text { - } \text { Relative humidity accuracy of } \pm 3 \% \text { and } \\
\text { measuring range between } 1 \text { and } 99 \% \\
\text { with } 1 \% \text { resolution. } \\
\text { - Transmitters: } \\
\text { - } \quad \text { Temperature accuracy of } \pm 1{ }^{\circ} \mathrm{C} \text { and } \\
\text { measuring range between } 39.6^{\circ} \mathrm{C} \text { and } \\
+59.9^{\circ} \mathrm{C} \text { with } 0.1{ }^{\circ} \mathrm{C} \text { resolution; } \\
\text { Relative humidity accuracy of } \pm 3 \% \text { and } \\
\text { measuring range of } 1-99 \% \text { with } \\
1 \% \text { resolution. }\end{array}$ & $\begin{array}{l}\text { Datalogger: Living } \\
\text { room/Kitchen } \\
\text { Transmitters: } \\
\text { Bedrooms, Bathroom }\end{array}$ \\
\hline AG, model Testostor & $\begin{array}{l}\text { - Temperature accuracy of } \pm 0.9^{\circ} \mathrm{C} \text { and a } \\
\text { temperature measuring range between } \\
-10^{\circ} \mathrm{C} \text { and }+50^{\circ} \mathrm{C} \text {, with } 1{ }^{\circ} \mathrm{C} \text { resolution. } \\
\text { - Relative humidity measuring ranges } \\
\text { from } 0 \text { to } 100 \% \text {, with a resolution of } 1 \% \text {. }\end{array}$ & Outdoor \\
\hline
\end{tabular}

Multifunction climate measuring instrument with the IAQ probe for $\mathrm{CO}_{2}$ and absolute pressure (Testo AG, Testo 435)

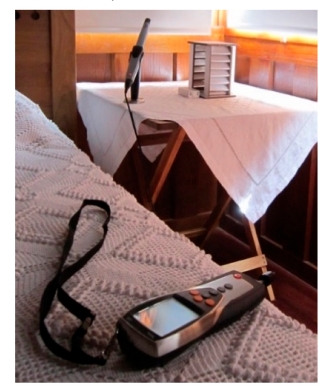

Probe for ambient $\mathrm{CO}_{2}$ :

- Measuring range from 0 to $10,000 \mathrm{ppm}$.

- Accuracy $\pm(75 \mathrm{ppm} \pm 3 \%$ of $\mathrm{mv})(0$ to $+5000 \mathrm{ppm}) \pm(150 \mathrm{ppm} \pm 5 \%$ of $\mathrm{mv})$ (+5001 to $10,000 \mathrm{ppm})$

Absolute pressure:

All rooms

- Measuring range from +600 to $+1150 \mathrm{hPa}$.

- Accuracy of $\pm 10 \mathrm{hPa}$.

Determination of radon content using a portable ATMOS 12 PDX sensor

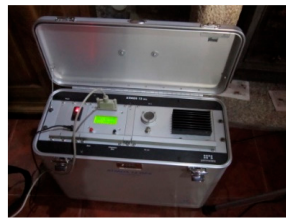

Instrument:

- Measurement operation (Temperature range from 0 to $50{ }^{\circ} \mathrm{C}$; Humidity range from 0 to $90 \%$ ).

- Pulse counting ionisation chamber.

- $10 \%$ standard deviation at $800 \mathrm{~Bq} / \mathrm{m}^{3}$ and $10 \mathrm{~min}$ measurement time.

- Upper limit for radon gas content detection is $100,000 \mathrm{~Bq} / \mathrm{m}^{3}$;

- $\quad$ Air pump for continuous flow of 1.4 $1 / \mathrm{min}$. Airflow through the chamber 1.0 $1 / \min$.

- $\quad$ Memory with capacity for 28 days of time distribution and 20 energy spectra

- $10 \mathrm{~min}$ interval measurements (it allows $1,5,10,30 \mathrm{~min}$ and $1,8,24 \mathrm{~h}$ ).

\subsection{Long-Term Monitoring}

Long-term monitoring was carried out to measure the indoor and outdoor air temperatures and relative humidity throughout the measurement period. For this, thermo-hygrometer sensors were installed in the most representative rooms and outdoors (Table 1). The measurements were carried 
out during different monitoring campaigns for all seasons, in compliance with specified procedures and standards (ISO 7726 [30], ISO 7730 [31], and ASHRAE 55 [32]). The monitoring campaigns were carried out for periods of at least 25 days and with the sensors recording data in periods of $30 \mathrm{~min}$. Results on indoor environmental parameters were correlated with the outdoor parameters. During the measurement period, occupants filled an occupancy table where they recorded how they used the building, i.e., if they used the heating or cooling systems and promoted ventilation, among other effect. These occupancy records were useful to understand, for example, sudden changes in air temperature and relative humidity profiles. Local weather data was collected from the nearest weather stations.

\subsection{Model of Thermal Comfort}

An adaptive model of thermal comfort was used in the analysis of thermal comfort conditions since this is the adequate model for naturally conditioned buildings. The chosen model was the Portuguese adaptive model of thermal comfort, to be more representative of the Portuguese reality [33]. This model is an adaptation to the Portuguese context of the models specified in standards ASHRAE 55 [32,34] and EN 15251 [35]. It considers the typical climate and ways of living and how buildings are conventionally designed and used. According to this model [33]: (i) occupants may tolerate broader temperature ranges than those indicated for mechanically heated and/or cooled buildings; and ii) the outdoor temperature has a strong influence on occupants' thermal perception/sensation.

In the application of the proposed model to the case study, the following conditions were assumed: (i) the occupants have activity levels that result in metabolic rates (met) ranging from 1.0 to 1.3 met (sedentary activity levels); (ii) occupants are free to adapt their clothing for thermal insulation; (iii) air velocity below $0.6 \mathrm{~m} / \mathrm{s}$; (iv) indoor operative temperature between $10{ }^{\circ} \mathrm{C}$ and $35^{\circ} \mathrm{C}$; and (v) outdoor running mean temperature between $5{ }^{\circ} \mathrm{C}$ and $30^{\circ} \mathrm{C}$. The building has no air-conditioning system, or its use is sporadic, and, therefore, in the analysis of the case study, the adaptive model for building without mechanical systems was applied.

Considering that an individual takes approximately one week to be fully adjusted to the changes in outdoor climate, the thermal comfort temperature (indoor operative temperature, $\Theta_{0}$ ) is obtained from the exponentially weighted running mean of the outdoor temperature during the last seven days (outdoor running mean temperature, $\Theta_{r m}$ ). The calculation of the exponentially weighted running mean of the outdoor temperature in the previous seven days is done using Equation (1).

$$
\Theta_{r m}=\left(T_{n-1}+0.8 T_{n-2}+0.6 T_{n-3}+0.5 T_{n-4}+0.4 T_{n-5}+0.3 T_{n-6}+0.2 T_{n-7}\right) / 3.8
$$

where:

$\Theta_{r m}\left({ }^{\circ} \mathrm{C}\right)$ - exponentially weighted running mean of the outdoor air temperature;

$T_{n-i}\left({ }^{\circ} \mathrm{C}\right)$ - outdoor mean air temperature of the previous day (i).

In this model, two comfort temperatures ranges are defined, one to be applied in spaces with active air-conditioning systems and the other in non-air-conditioned spaces (which do not have air-conditioning systems or systems which are turned off). The operative temperature limits defined in this model are for $90 \%$ of acceptability, these limits are up to $3{ }^{\circ} \mathrm{C}$ above or below the estimated comfort temperature both for non-air-conditioned spaces $\left(\Theta_{0}=0.43 \Theta_{r m}+15.6\right)$ and air-conditioned spaces $\left(\Theta_{o}=0.30 \Theta r m+17.9\right)$.

The operative temperature was calculated based on the results obtained in the measurements from the thermal microclimate station. With the operative temperature $\left(\Theta_{0}\right)$ and the outdoor running mean temperature $\left(\Theta_{r m}\right)$ is possible to represent in the adaptive chart, the point that characterises the thermal environment condition in the moment of measurement. 


\section{Description of the Case Study}

\subsection{Site and Climate}

The case study is located in the old village of Granja do Tedo, in the municipality of Tabuaço, district of Viseu, Northern Portugal (Figure 2). The Granja do Tedo territory has an ancient history, with a rich medieval past and some archaeological remains dating back to the Romans (as the bridge over the river Tedo) [36]. The village is strategically implanted in the lower part of a valley, next to the confluence between the river Tedo (that flows to the river Douro) and of other two streams. The village is divided by the river in lower and upper parts (Figure 3). The implantation favours a good solar exposure from south (particularly in the upper part of the village located on a south-facing slope), and the surrounding mountains offer protection against the wind (Figure 4). The implantation in the valley also provides a more favourable microclimate, warmer than the one of the higher areas of the territory. Nearby, the available soils are good for agriculture [37]. At a geological level, the area is dominated by granitoids of different types and ages (Figure 5), confirming the abundancy of this resource and its use in the village as the primary building material [38].

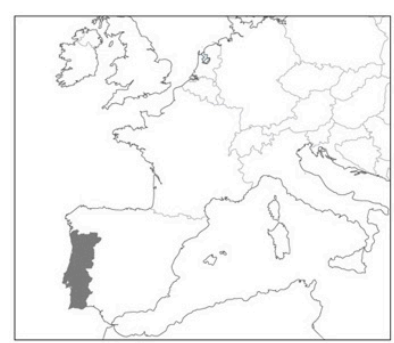

(a)

(a)

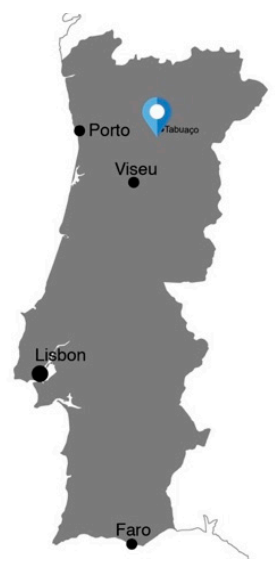

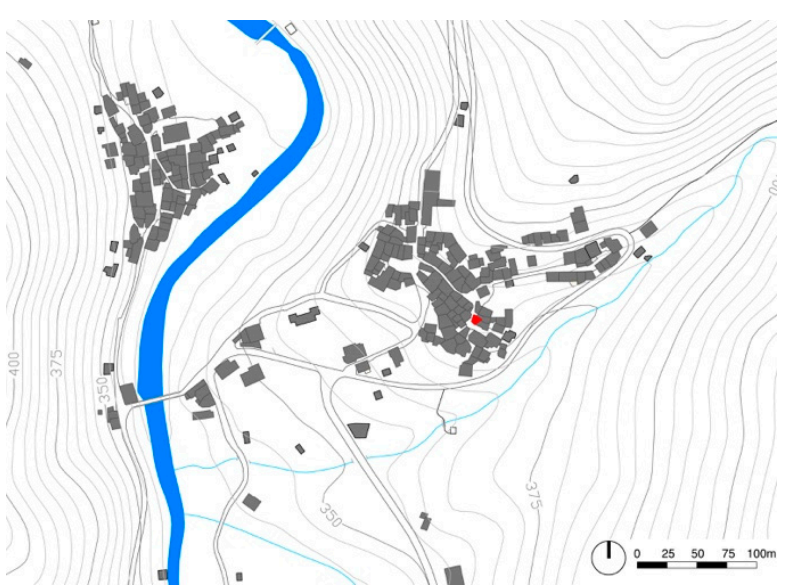

(b)

Figure 2. Case study's location. (a) country context; (b) Granja do Tedo's urban layout.

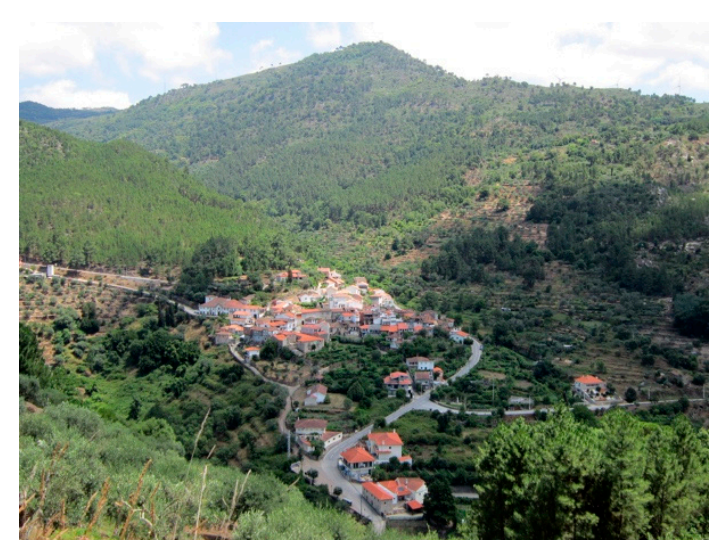

(a)

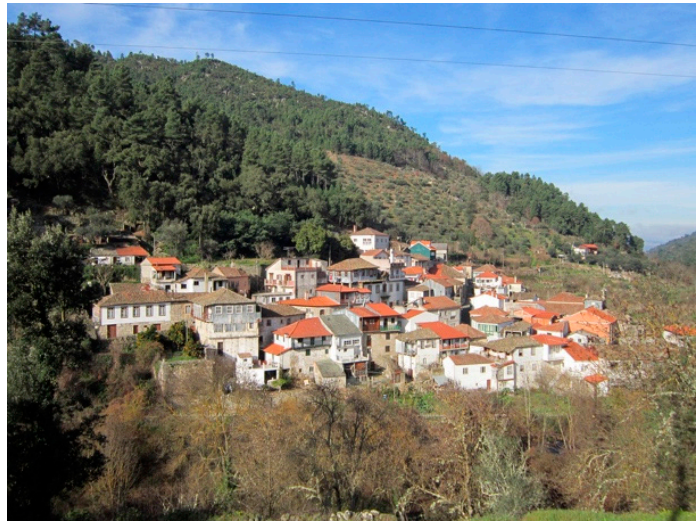

(b)

Figure 3. Granja do Tedo. (a) Upper part; (b) lower part. 


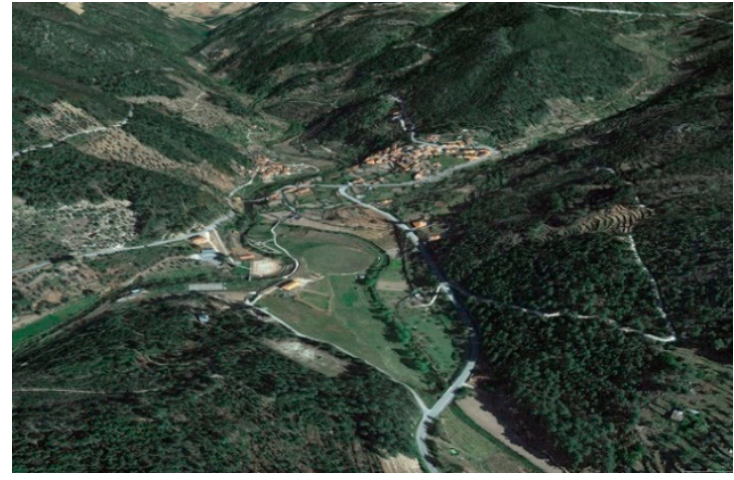

(a)

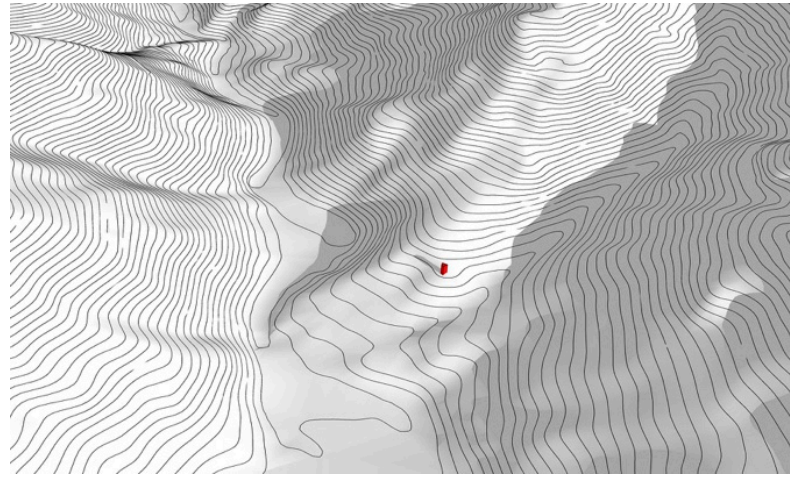

(b)

Figure 4. Granja do Tedo's context. (a) Aerial view with terrain relief (Google Earth); (b) Tridimensional model of the terrain showing the solar exposure at 9:30 a.m. on the winter solstice (case study location marked in red).

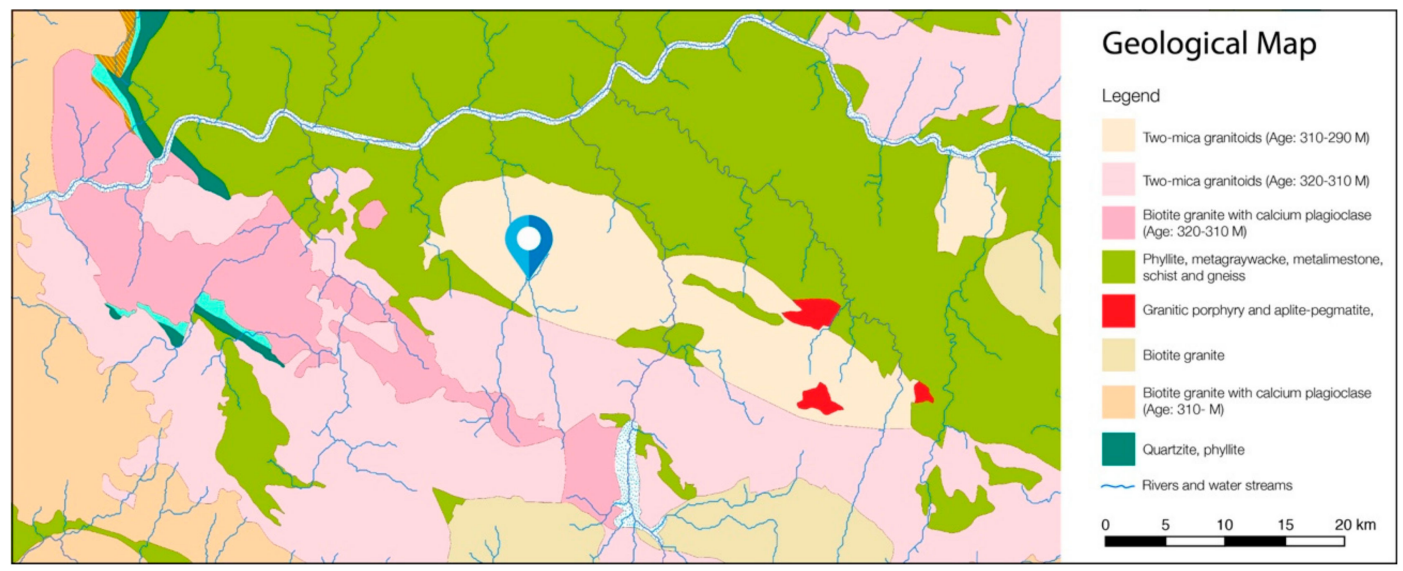

Figure 5. Geological map of Granja do Tedo area (adapted from [38]).

The village has a compact urban layout with narrow and winding streets, and most of the built area is implanted on a rocky massif (Figures 2 and 3), sparing the fertile agriculture land near the watercourses.

The village is mostly composed of two- and three-storey buildings, where the ground floor is commonly used to store goods and/or livestock, and the upper floors are for human occupancy. The wooden balconies (open or glazed) are frequent in the village. Due to sun exposure these were spaces used to dry grains and fruits and also for sewing. Additionally, like other constructions in regions with cold winters, buildings have very few and small openings to avoid heat losses. The compact layout and form also allow for reducing heat losses through the building envelope.

The Douro Valley region has a temperate climate-Type C, according to Köppen-Geiger Climate Classification, co-existing the sub-types Csa (temperate with hot and dry summer) and Csb (temperate with dry or temperate summer) (Figure 6a) [39]. Granja do Tedo is located in a narrow valley connected to the river Douro valley, and in the transition between the two climate subtypes [39]-The Csa in the valley and the $\mathrm{Csb}$ in the higher altitude areas. The annual average mean temperature is of $17.5^{\circ} \mathrm{C}$. The average mean temperature in winter is of $10.0^{\circ} \mathrm{C}$, while in summer is between 22.5 and $25.0^{\circ} \mathrm{C}$ (Figure 6b,c) [39]. Winter is the harshest season in this area. Excluding the valley, the mean temperature in winter is of $7.5^{\circ} \mathrm{C}$. The average maximum air temperature in winter varies between 12.5 and $15.0^{\circ} \mathrm{C}$, while the average minimum air temperature is of $5.0^{\circ} \mathrm{C}$ [39]. In winter, there are 10 to 20 days with a minimum temperature below or equal to $0^{\circ} \mathrm{C}$ (Figure $6 \mathrm{~d}$ ), whereas the surrounding area has around 40 days [39]. 


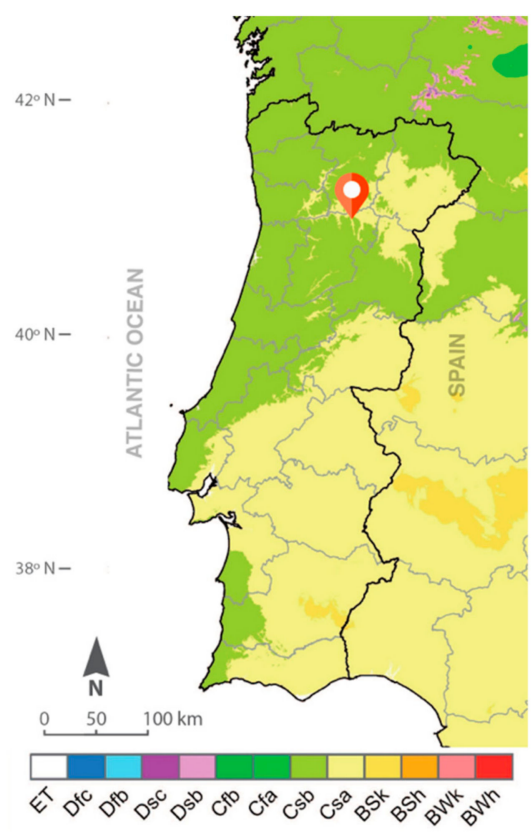

(a)

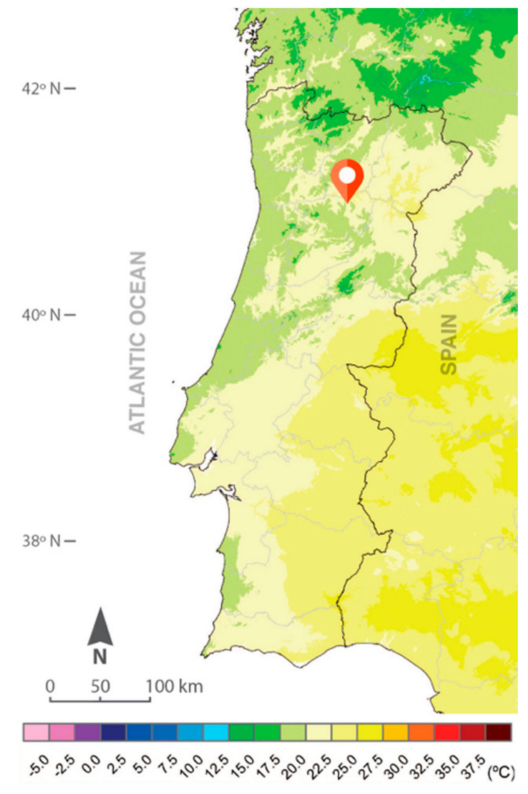

(c)

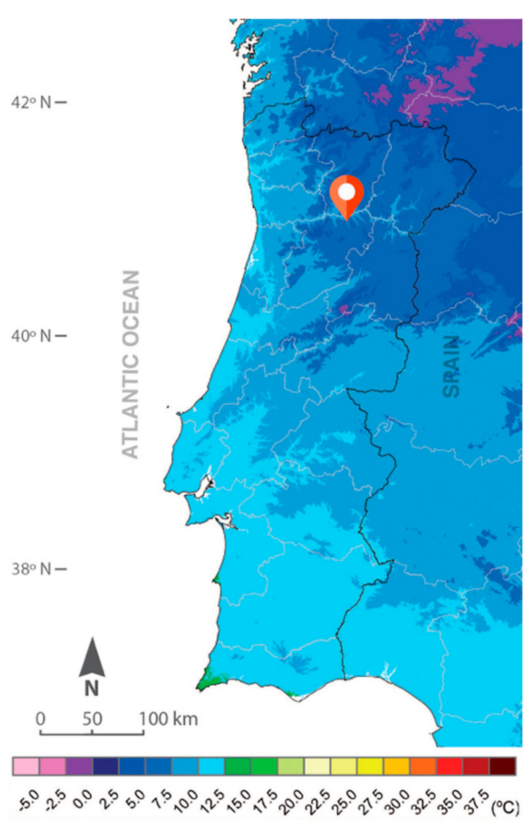

(b)

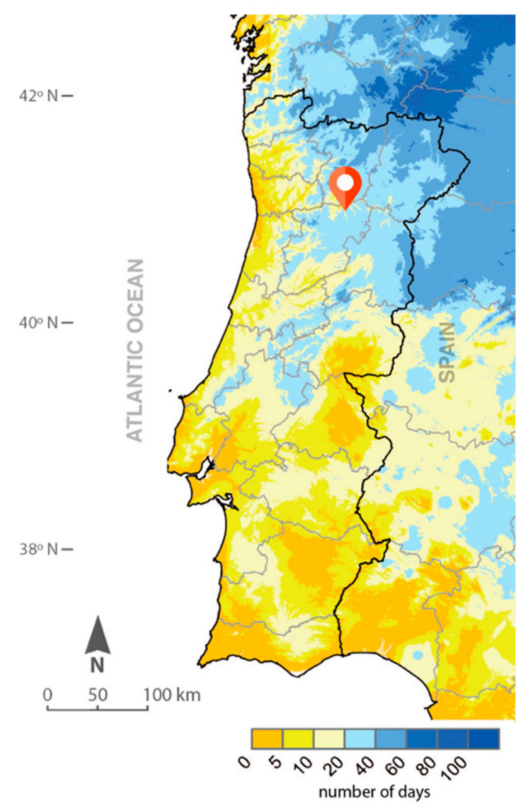

(d)

Figure 6. (a) Köppen-Geiger Climate Classification for Portugal; (b,c) Average mean temperature in winter and summer; (d) Average number of days with minimum temperature $\leq 0^{\circ} \mathrm{C}$ in winter (adapted from [39]).

\subsection{Building}

The selected case study is a representative glazed-balcony building of Northern Portugal vernacular architecture [29], presenting a set of strategies to promote heat gains and reduce heat losses. The construction date is unknown, but considering the ages of neighbour buildings, and according to the owners, the case study is probably from the 18th century.

The building is a semi-detached single-family house, integrated into the urban mesh (Figure 7). It has an irregular floor plan and the main façade with the balcony is facing southwest, while the others are facing northeast, southeast, and west (Figure 8). As other constructions in regions with cold winters, and apart from the balcony that has the purpose of harvesting solar gains, the building has 
only two windows to avoid heat losses (one at the west, facing the street, a small one facing southeast and none at the north quadrant). The gross floor area is of approximately $50 \mathrm{~m}^{2}$ divided into two floors.

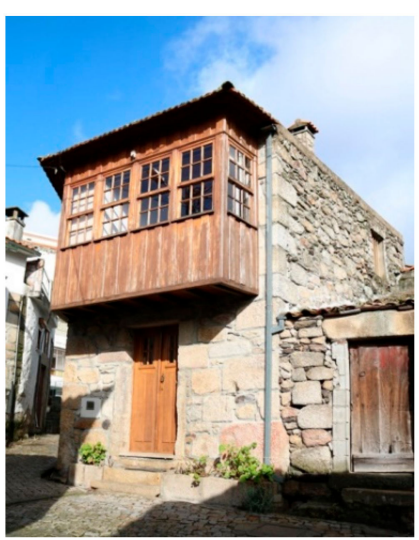

(a)

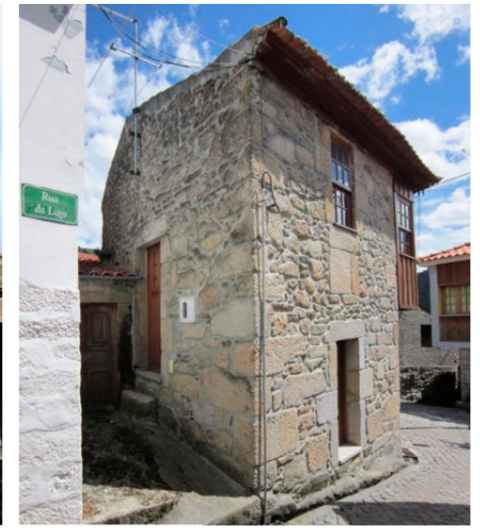

(b)

Figure 7. External views. (a) southwest and southeast façades; (b) northeast and west facades.

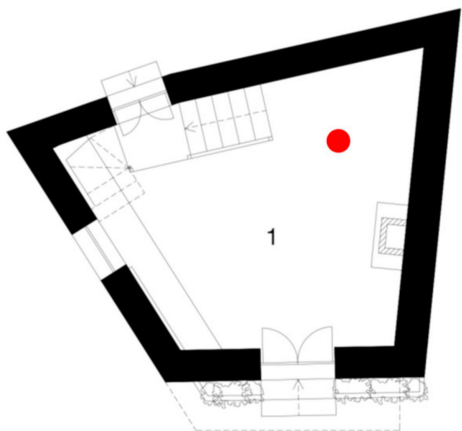

ground floor

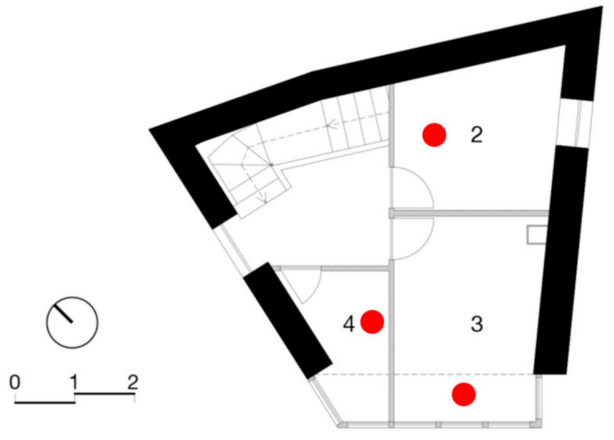

upper floor

Figure 8. Floor plans showing the location of measuring instruments (1-living room/kitchen; 2-bedroom; 3-bedroom with balcony; 4-bathroom).

The building was renovated in 2005. During this intervention, some changes were introduced in the layout and use of some rooms. Some improvements were also implemented, such as the installation of a bathroom, renovation of windows and doors, the ground floor was paved, renovation of the timber balcony structure, and fitting thermal insulation to the ceiling. In the renovation, the ground floor was converted into a kitchen and living room (Figure 9a), and the upper floor layout was reorganized to accommodate two bedrooms and a bathroom (Figure 9b). In this modification of the floorplan, the partition wall of the balcony and other walls were removed to increase the floor area of the bedrooms and bathroom (Figure 9c). 


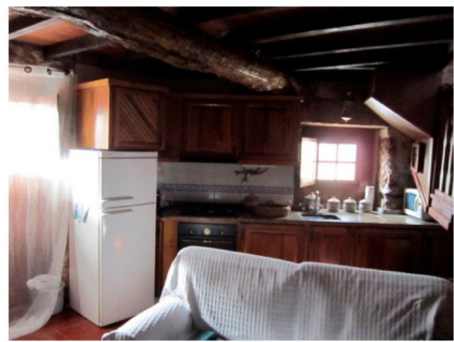

(a)

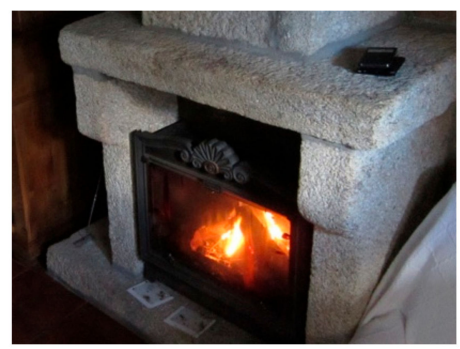

(d)

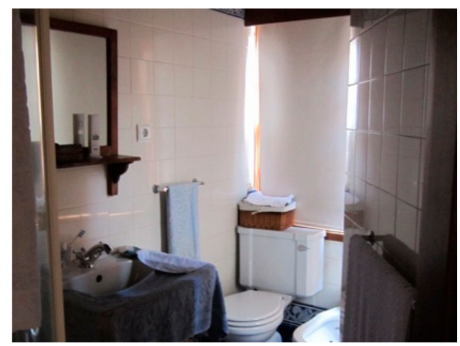

(b)

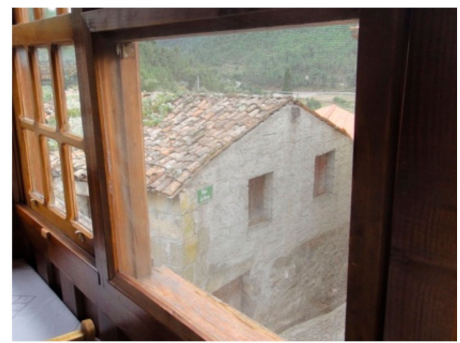

(e)

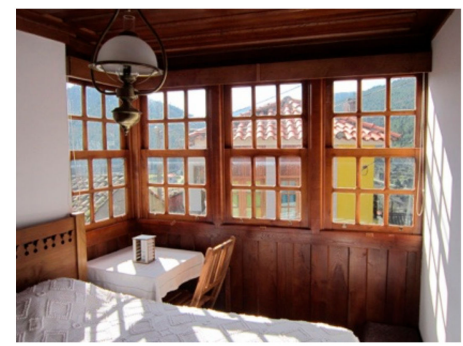

(c)

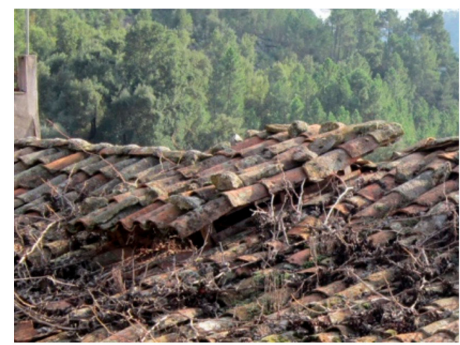

$(\mathbf{f})$

Figure 9. (a) Kitchen view; (b) bathroom view; (c) bedroom with balcony; (d) closed wood-burning fireplace; (e) removable ventilation net; (f) smoke exhaust by the roof.

The building envelope consists of granite walls (50-55 cm thick) with a pitched roof, wooden doors, and wooden framed single glazed windows. Indoors, the partitions walls in tabique (earth-filled timber frame walls) were replaced by plasterboard walls. The ground floor is now paved with ceramic tiles, and the upper floor has a wooden floor with timber structure. Table 2 lists the thermal transmittance coefficient ( $U$-value) of the building envelope. The building has no cooling system, and the heating system is a closed wood-burning fireplace (Figure 9d).

Table 2. Characteristics of the building envelope.

\begin{tabular}{|c|c|c|}
\hline Envelope Element & Materials & $U$-Value $\left(\mathrm{W} /\left(\mathrm{m}^{2} \cdot{ }^{\circ} \mathrm{C}\right)\right.$ \\
\hline External walls & Granite $(50-55 \mathrm{~cm})$ & $2.87[40]$ \\
\hline Ceiling (in contact with ventilated roof) & $\begin{array}{l}\text { Ceiling with timber structure with } 4 \mathrm{~cm} \text { of extruded } \\
\text { polystyrene (XPS) }\end{array}$ & $0.84[41]$ \\
\hline Doors & Wood & $2.15[41]$ \\
\hline Windows & $\begin{array}{l}\text { Wooden single glazed windows, indoor wooden } \\
\text { shutters }\end{array}$ & $3.40^{*}[41]$ \\
\hline Windows (balcony) & $\begin{array}{l}\text { Wooden single glazed sash windows, indoor opaque } \\
\text { curtains }\end{array}$ & $4.30 *[41]$ \\
\hline Balcony (lower part) & Timber frame (double wooden panel) $(10 \mathrm{~cm})$ & $1.70[41]$ \\
\hline
\end{tabular}

${ }^{*} U_{w d n}$-day-night thermal transmittance coefficient, including the contribution of the shading systems.

\subsection{Passive Strategies}

In the inland northern part of Portugal, to respond to a climate of harsher winter conditions and milder summers, vernacular architecture developed specific mitigation strategies. These had, in general, the purpose of increasing solar gains and reducing heat losses during winter, like the ones found in this case study:

- Balconies are an architectonic feature and identity of Northern Portugal vernacular architecture. It has to be taken into consideration that most of these buildings had low daylight levels and comfort conditions. Therefore, balconies were spaces used to enjoy the sun, work with daylight, and to heat the adjacent spaces, particularly on sunny winter days. The glazed balcony is an improved version of a balcony, that acts as a sunspace, allowing to harvest solar gains and reduce heat losses (Figure 9c). In the case study, the larger area of the balcony is facing southwest, with 
parts facing southeast and west. Therefore, in winter, the balcony is exposed to a higher solar radiation level during a larger number of sunshine hours. Although this strategy is aimed for the heating season, the cantilevered volume of the balcony and the possibility to keep windows open without compromising security also allows proper operation during the cooling season (Figure 9e), by shading the walls and promoting natural ventilation (Figure 10);

- To reduce heat losses, only a few windows (upper floor) face directly outdoors. In the original configuration of building, the balcony acted as buffer space and only some indoor rooms connected directly to the outdoors (Figure 9c); additionally, and although it was not possible to verify if it was the case of this building, sometimes to reduce heat losses by ventilation, buildings did not have chimneys and the exhaust of smoke was done through the roof, as it is still visible in a neighbouring building (Figure 9f);

- The use of high thermal inertia building elements, namely the massive granite walls and the massif rock where the building is laying, gives the building the capacity to stabilize indoor temperature;

- The functional arrangement of the indoor spaces in this type of buildings (as it was the case of this building before the renovation), can also reduce the heating needs. In this type of architecture, bedrooms rarely had exterior windows and were located next to the kitchen, taking advantage of the heat generated by the fireplace;

- The storage of the livestock on the ground floor was also a heating strategy. After the renovation, this strategy is mimicked by the closed wood-burning fireplace;

- The organic and compact urban layout, suited to the topography, can also be considered a passive strategy since the compactness of constructions allows to minimize the area of the envelope exposed to outdoor conditions and therefore reduce heat losses. The narrow and winding streets allow reducing wind speed, and in some places, the streets form small 'public-patios' sheltered from the prevailing winds (Figures 2 and 3).

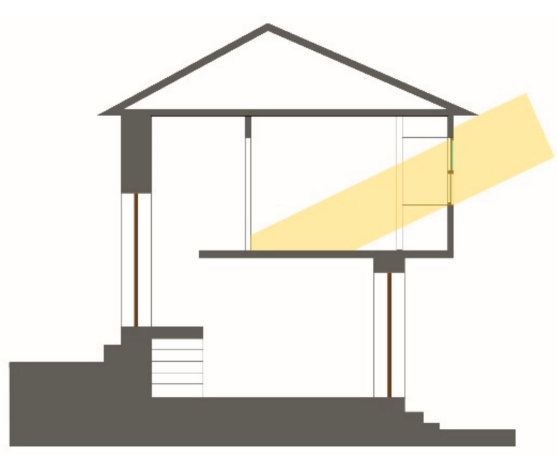

(a)

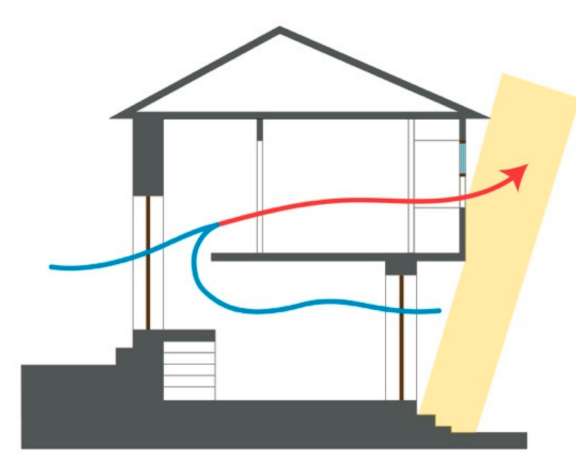

(b)

Figure 10. Schematic section of the glazed balcony operation. (a) Winter solstice; (b) Summer solstice.

The combination of all these passive strategies has the main purpose of achieving the better possible indoor thermal comfort conditions. The range of strategies highlights the poor living conditions and the need to understand and use the available resources the best way possible.

The dissemination of the abovementioned strategies in the region highlights their usefulness in mitigating the effects of the cold climate, as shown in previous studies [26,27]. Therefore, the quantitative study of the effectiveness of these passive strategies, particularly of the glazed balcony, and their effect on the thermal performance is useful to the discussion about the energy efficiency of buildings in this region. This is described and discussed in the following sections. 


\subsection{Occupancy Profile}

It is essential to know the building occupancy profile since the daily occupants' habits have a direct influence on the thermal performance of the building [32]. The studied building is a holiday house, mainly used for weekends and holidays. During the summer period (vacations), it is occupied continuously during one or two months. The building is only used sporadically during the remainder of the year. Table 3 summarizes the main activities reported by the occupants (during the occupancy period) that may influence the thermal performance of the building. It is important to note that the building was unoccupied during most of the winter monitoring period.

Table 3. Building occupancy profile.

\begin{tabular}{|c|c|c|}
\hline & Season & Use and Description \\
\hline Autumn & $\begin{array}{l}\text { Heating/Cooling } \\
\text { Ventilation } \\
\text { Shading }\end{array}$ & $\begin{array}{l}\text { The closed wood-burning fireplace was in operation. } \\
\text { The windows remained closed. } \\
\text { The curtains were usually opened in the morning } \\
\text { (around 9:30 a.m.) and closed at night. }\end{array}$ \\
\hline Winter & $\begin{array}{l}\text { Heating/Cooling } \\
\text { Ventilation } \\
\text { Shading }\end{array}$ & $\begin{array}{l}\text { The closed wood-burning fireplace was in operation } \\
\text { from 6:00 p.m. until } 12 \text { p.m. } \\
\text { Sporadic opening of windows for ventilation. } \\
\text { The curtains were usually opened during the day and } \\
\text { closed during the night. }\end{array}$ \\
\hline Spring & $\begin{array}{l}\text { Heating/cooling } \\
\text { Ventilation } \\
\text { Shading }\end{array}$ & $\begin{array}{l}\text { No cooling system was used. } \\
\text { Daily opening of the window for ventilation (8:30 a.m. to } \\
6 \text { 6:30 p.m.). } \\
\text { The curtains were usually opened during the day and } \\
\text { closed during the night. }\end{array}$ \\
\hline Summer & $\begin{array}{l}\text { Heating/cooling } \\
\text { Ventilation }\end{array}$ & $\begin{array}{l}\text { No cooling system was used. } \\
\text { The windows were open day and night. Mosquito nets } \\
\text { were placed in the windows to allow for ventilation } \\
\text { during night time. } \\
\text { The bedroom/balcony curtains remained open in the } \\
\text { morning only until the direct sun passes through the } \\
\text { window (around 1:00 p.m.). }\end{array}$ \\
\hline
\end{tabular}

\section{Results and Discussion}

\subsection{Thermal Monitoring and Indoor Comfort Evaluation}

The thermal performance monitoring included the assessment of the air temperature and relative humidity. Additionally, the indoor comfort conditions in the main rooms of the case study were characterized. These parameters were evaluated over one year, and data here presented are for 30 representative days of each season.

\subsubsection{Autumn}

During Autumn monitoring (from 8th November to 8th December 2014), the outdoor mean air temperature was of about $10.6{ }^{\circ} \mathrm{C}$ (Table 4). The daily maximum and minimum outdoor air temperatures had some variations during the monitoring period. In the second half of the monitoring period, starting from 23 November (Figure 11), these variations were more frequent and significative. 
Table 4. Comparison between outdoor and indoor air temperatures and relative humidity values during autumn.

\begin{tabular}{cccccc}
\hline \multicolumn{7}{c}{ Autumn } \\
\hline Place/Room & Outdoor & $\begin{array}{c}\text { Kitchen/Living } \\
\text { Room }\end{array}$ & Bedroom/Balcony & Bedroom & Bathroom \\
\hline \multicolumn{7}{c}{ Temperature $\left(^{\circ} \mathbf{C}\right)$} \\
Mean & 10.1 & 12.1 & 12.6 & 11.5 & 11.5 \\
Maximum & 24.6 & 14.3 & 18.9 & 15.2 & 16.4 \\
Minimum & -0.3 & 9.2 & 6.5 & 8.5 & 6.6 \\
\hline Mean & 84.1 & Relative Humidity $\mathbf{( \% )}$ & 78.9 & 77.9 \\
Maximum & 96.8 & 75.7 & 72.5 & 82.0 & 85.0 \\
Minimum & 32.3 & 79.0 & 79.0 & 69.0 & 70.0 \\
\hline
\end{tabular}

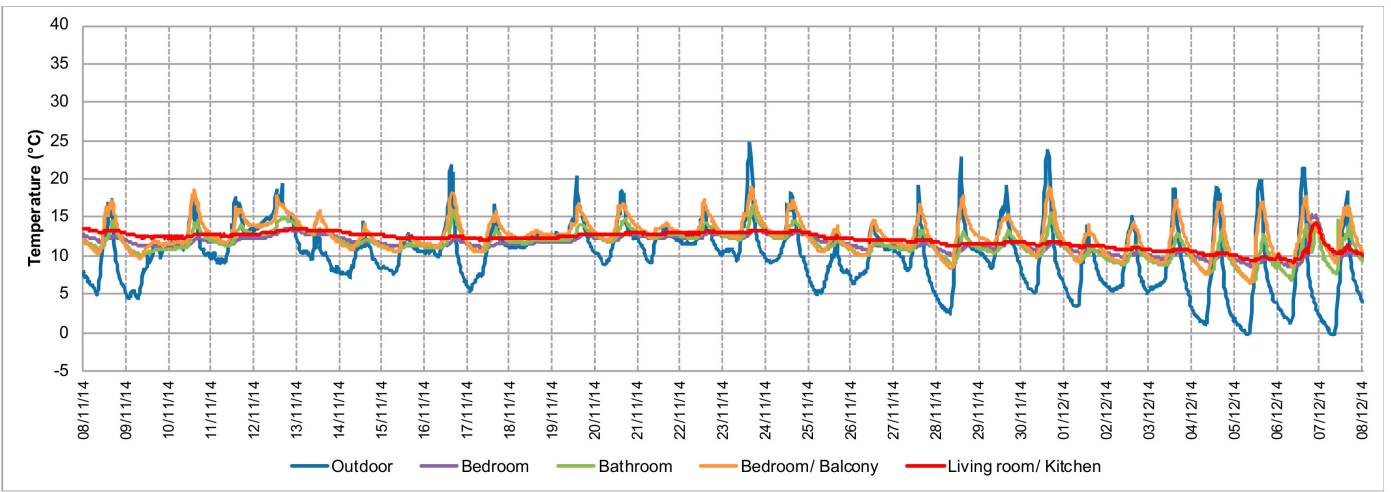

(a)

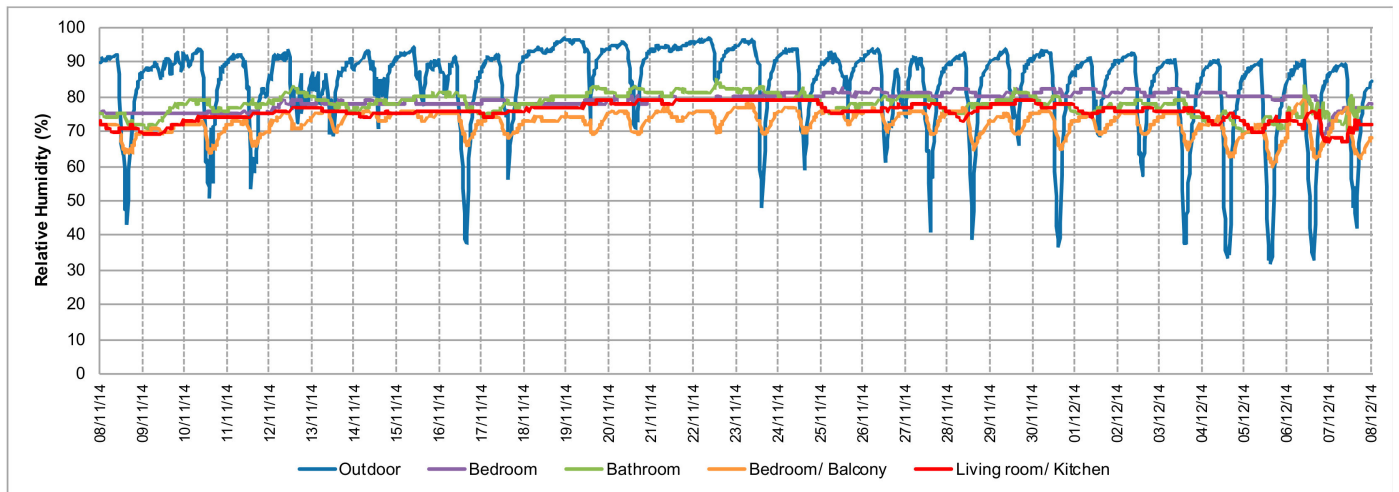

(b)

Figure 11. Autumn monitoring: (a) Indoor and outdoor air temperature profiles; (b) Indoor and outdoor air relative humidity profiles.

Figure 11a shows that indoor temperature remained stable in the rooms with a smaller glazing area, with a mean temperature of $12.1^{\circ} \mathrm{C}$ in the living room/kitchen and $11.5^{\circ} \mathrm{C}$ in the bedroom (Table 4). The reduced glazed area and the high thermal inertia of the building envelope allow stabilization of the indoor temperature in these rooms. On 7 December, when the outdoor temperature reaches a minimum value of $1.2{ }^{\circ} \mathrm{C}$, it is possible to observe how building occupants can take correcting measures to improve the indoor thermal comfort conditions. The increase of the indoor temperatures in the living room/kitchen and bedroom (Figure 11a) is due to the use of the heating system (closed wood-burning 
fireplace). According to Table 4 and Figure 11a), in these rooms, the maximum temperatures were always below the comfort temperature range.

In the rooms where the glazing area is predominant, bedroom/balcony and bathroom, it was observed that the indoor temperature was not stable as it is strongly dependent on the outdoor climate conditions. The maximum temperature recorded in the bedroom/balcony was of $18.9^{\circ} \mathrm{C}$ while in the bathroom was of $16.4^{\circ} \mathrm{C}$ (Table 4). In these rooms, during the day, the indoor temperature followed the trend of the outdoor temperature (Figure 11a). The temperature profiles in both rooms were quite similar, but since the bedroom/balcony has a larger glazed area than the bathroom, it presented higher temperatures. The bedroom/balcony had the highest indoor temperature throughout the monitoring period, reaching temperatures close to the comfort threshold temperature. These results highlight the effect of the glazed balcony as a strategy to capture solar gains.

Concerning the outdoor relative humidity, it was found that there was a high daily variation, reaching values of around $90 \%$ during the night and lower figures of $32.3 \%$ during the day (Table 4 ). The average outdoor relative humidity value was also high, being $84.1 \%$ during the monitoring period (Table 4). In contrast, almost all indoor rooms had stable relative humidity profiles with small daily variations. The exception was the bedroom/balcony, where the fluctuations were slightly higher than the other rooms, due to higher solar radiation, but much lower than the variations outdoors. The indoor relative humidity values were high (about 70-80\%), higher than those recorded outdoors during the day, but smaller than those verified outdoors during the night. The reduced ventilation rate of the rooms, due to the lack of occupancy, might be the main reason for the high indoor relative humidity levels. During the occupancy period (from 7 to 8 December, 2014) there was a slight decrease in the relative humidity level in the living room and bedroom (Figure 11b) due to the use of the heating systems. However, due to the low outdoor temperatures, the ventilation was minimized to reduce heat losses.

Regarding the assessment of the thermal comfort, the measurements in the living room/kitchen and bedroom/balcony were carried out when the heating system was not used. The influence of the curtains on the thermal comfort in the bedroom/balcony was also evaluated. In autumn and without the use of the heating system, the results showed that the thermal comfort conditions in the living room/kitchen were below the lower comfort limit (Figure 12a). In the survey, the two inhabitants answered as being "slightly cool" (1.0 met; 0.91 clo) and one as being "cool" (1.0 met; 0.95 clo), confirming the objective measurements. In what concerns the assessment of the thermal comfort conditions in the bedroom/balcony, it was possible to verify the influence of the glazing area. In this room, when the curtains were closed, the comfort conditions were within the thermal comfort limits, but close to the bottom threshold (blue dot in Figure 12b). In the survey, the two occupants answered as being 'neutral' (comfortable) (1.0 met; $0.91-0.95$ clo), i.e., results were in line with the objective assessment. When the curtains were open, the solar gains increased the operative temperature, and thermal conditions were above the upper thermal comfort threshold, showing an overheating period (red dot in Figure 12b). 


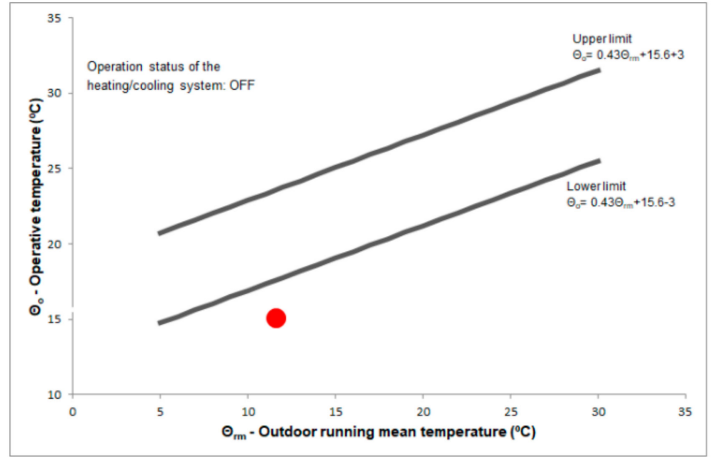

(a)

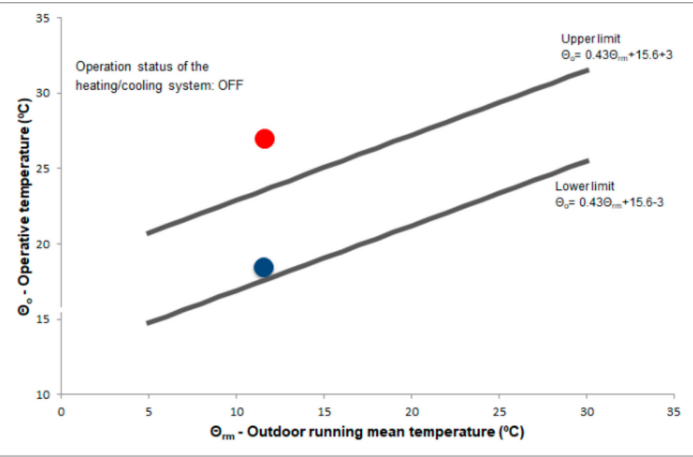

(b)

Figure 12. Adaptive comfort chart during a representative autumn day: (a) Thermal comfort temperature (operative temperature) in the living room/kitchen; (b) Thermal comfort temperature (operative temperature) in the bedroom/balcony for open curtains (red dot) and closed curtains (blue dot).

\subsubsection{Winter}

The winter monitoring was carried out between 27 December 2014 and 27 January 2015. In this period, the minimum outdoor temperature was very low, reaching a minimum value of $-4.0^{\circ} \mathrm{C}$ (Table 5), being around $0{ }^{\circ} \mathrm{C}$ most of the days. The maximum outdoor temperature reached $20.9^{\circ} \mathrm{C}$ (at the end of the monitoring period), and mean temperature did not exceed $4.6^{\circ} \mathrm{C}$.

Table 5. Comparison between outdoor and indoor air temperatures and relative humidity values during the winter.

\begin{tabular}{cccccc}
\hline \multicolumn{7}{c}{ Winter } \\
\hline Place/Room & Outdoor & $\begin{array}{c}\text { Kitchen/Living } \\
\text { Room }\end{array}$ & Bedroom/Balcony & Bedroom & Bathroom \\
\hline Mean & 4.6 & \multicolumn{7}{c}{ Temperature $\left(^{\circ} \mathbf{C}\right)$} \\
Maximum & 20.9 & 8.4 & 7.4 & 6.0 & 6.1 \\
Minimum & -4.0 & 5.2 & 15.7 & 8.2 & 12.8 \\
\hline Mean & 77.8 & Relative Humidity (\%) & 4.2 & 3.1 \\
\hline Maximum & 95.2 & 75.5 & 68.8 & 79.4 & 74.5 \\
Minimum & 14.7 & 80.0 & 76.0 & 83.0 & 85.0 \\
\hline
\end{tabular}

From the analysis of Figure 13a, it is possible to conclude that the living room/kitchen and the bedroom (the rooms with smaller glazed area and not in contact with the glazed balcony), showed a stable profile with low daily thermal variation and a mean temperature of $6.0^{\circ} \mathrm{C}$ and $6.4^{\circ} \mathrm{C}$, respectively (Table 5). Beyond the reduced glazed area, the thermal inertia of the envelope is the main reason for this steady behavior. The fact the building was not occupied during this period of the monitoring campaign explains the lower temperature values and their uniformity during the period, since there was no human action to achieve thermal comfort conditions (i.e., active heating to increase the indoor temperatures). Although considerably below the comfort limits, even in a free-running mode, it has to be highlighted that indoor mean temperature was always higher than outdoors. 


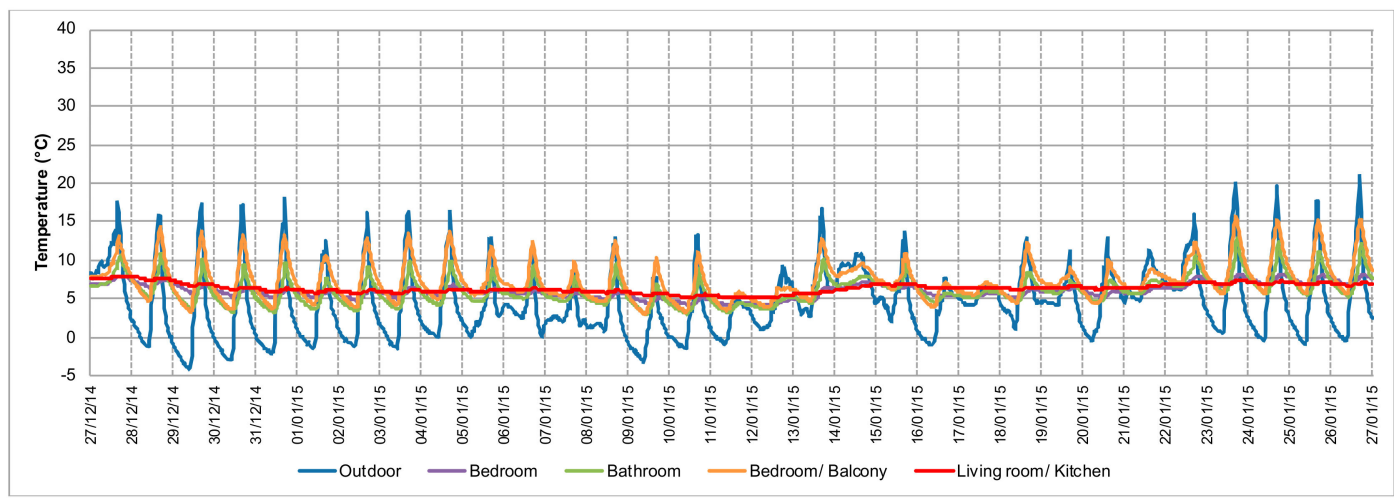

(a)

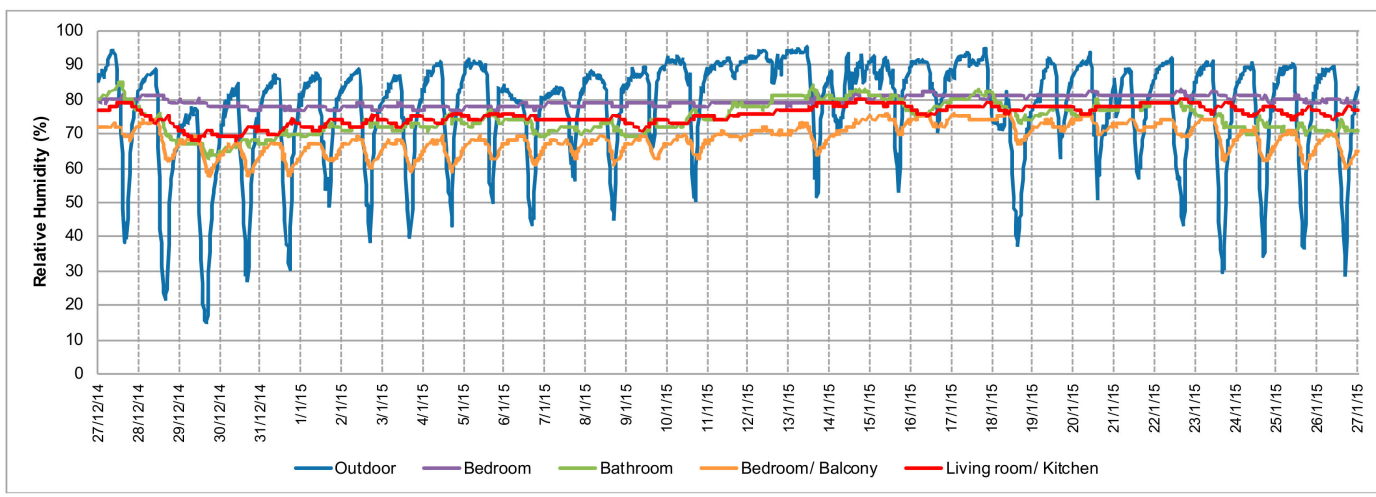

(b)

Figure 13. Winter monitoring: (a) Indoor and outdoor air temperature profiles; (b) Indoor and outdoor air relative humidity profiles.

Both in the bedroom/balcony and the bathroom, it was observed that temperature profiles were not stable and followed the outdoor temperature variation during the day (Figure 13a). The maximum indoor temperature recorded was of $15.7^{\circ} \mathrm{C}$ in the bedroom/balcony and $12.8^{\circ} \mathrm{C}$ in the bathroom, both in days with higher outdoor temperatures. Due to the large glazed area of the balcony, the effect of sunny days is visible in temperature peaks close to the thermal comfort boundary, even with this strategy not being used with full potential, since the opaque curtains were closed and therefore part of solar radiation was reflected. Consequently, in days with more incident radiation and if the curtains were open, it was expected that temperature would reach or be much closer to the comfort boundaries (similar to the condition measured during autumn and shown in Figure 12a, where active heating was only necessary as a backup). Nevertheless, there is also a drawback resulting from the greater glazed area, since these rooms also have more heat losses and therefore the minimum temperature recorded is lower than in the ground floor (Table 5). Moreover, the lack of thermal mass to store the heat gained during the day is a disadvantage, since the rooms have lightweight wooden floor and walls (as the original earth-filled timber frame walls_tabique - were replaced by plasterboard walls).

Considering that the glazed area is an important strategy to harvest solar gains, it was expected that these rooms had temperatures close to the comfort conditions, but mean temperature during the monitoring period was very low $\left(7.4^{\circ} \mathrm{C}\right)$ (Table 5). The non-occupation of the building and the use of the internal shading curtains during all monitoring period are the aspects that explain this behaviour.

Additionally, the temperature differences between ground and upper floors show how well the functional distribution of the rooms was before the building renovation. Originally, the ground floor was designed for storage and not for human occupancy, and in that case the stable and warm temperatures were an advantage. 
The outdoor relative humidity had significative daily variation, reaching values close to $96 \%$ during the night and a minimum of $14.7 \%$ during the day (Table 5). The average relative humidity of $77.8 \%$ is also high (Table 5). In general, the rooms have stable relative humidity profiles with little daily fluctuations. Rooms with smaller glazing area are the ones with the most stable temperatures. The bedroom/balcony showed the highest daily variation among the studied rooms, of about $8.0 \%$, being most of the monitoring period between 60 to $70 \%$.

Regarding the assessment of the thermal comfort (Figure 14), the measurement of the thermal environment conditions was performed during a typical winter day, in the bedroom/balcony and in the living room/kitchen. In the living room/kitchen, the analysis was carried out for two situations: (i) when the heating system was not in operation (Figure 14a); and (ii) when the heating system was in operation (Figure 14b). Results showed that when the heating system was not in operation the thermal environment was very uncomfortable (Figure 14a). The influence on the thermal comfort of using the closed wood-burning fireplace is quite evident, since when the heating system was in operation, the living room/kitchen had a comfortable thermal environment (Figure 14b). In the survey, the occupants also expressed their thermal sensation for the same two situations. When the heating system was not in operation, one occupant (1.0 met; $1.48 \mathrm{clo}$ ) answered as being "cool" and the other (1.0 met; $0.92 \mathrm{clo}$ ) as being "cold". When the heating system was in operation, one occupant (1.0 met; 1.48 clo) answered as being "neutral" and the other ( 1.0 met; 0.92 clo) as being "slightly cool". These results confirm the ones from the objective measurements. The differences between the answers of the two occupants are related to the different clothing insulation levels, which influenced their thermal sensation.

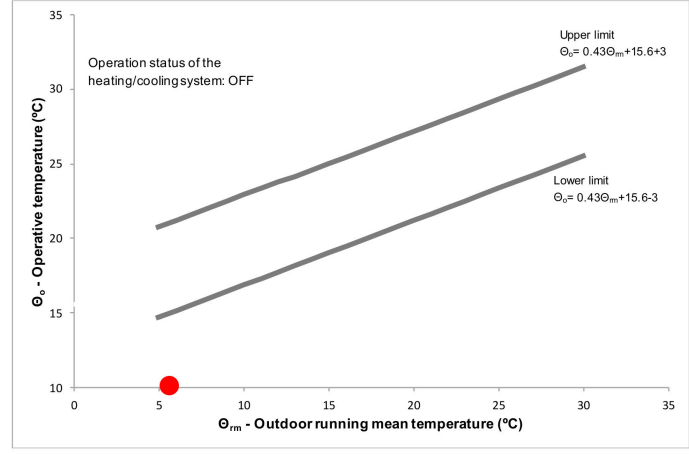

(a)

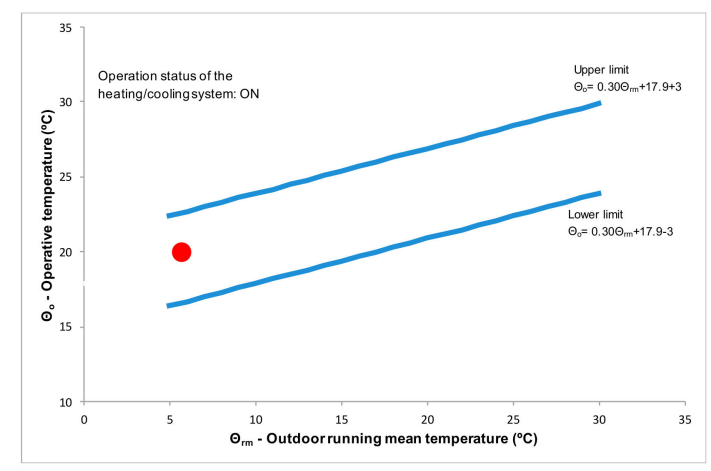

(b)

Figure 14. Adaptive comfort chart during a representative winter day: (a) Heating system OFF-Thermal comfort temperature (operative temperature) in the living room/kitchen; (b) Heating system $\mathrm{ON}$ - thermal comfort temperature (operative temperature) in the living room/kitchen.

In the bedroom/balcony, the measurements were carried out only when the heating system was not in operation. The thermal comfort conditions in this room were outside the comfort boundaries (Figure 15). Although the operative temperature was outside the comfort limits, it was very close to the lower comfort threshold. It is likely that the regular building occupation and, consequently, the appropriated use of the glazed balcony, would lead to an operative temperature within the comfort limits. It must be stressed that during the measurements, the sky was cloudy and thus solar gains were very low. In the survey, the two occupants answered as being "slightly cool" (1.0 met; 0.92-1.48 clo), which confirms the objective measurements. 


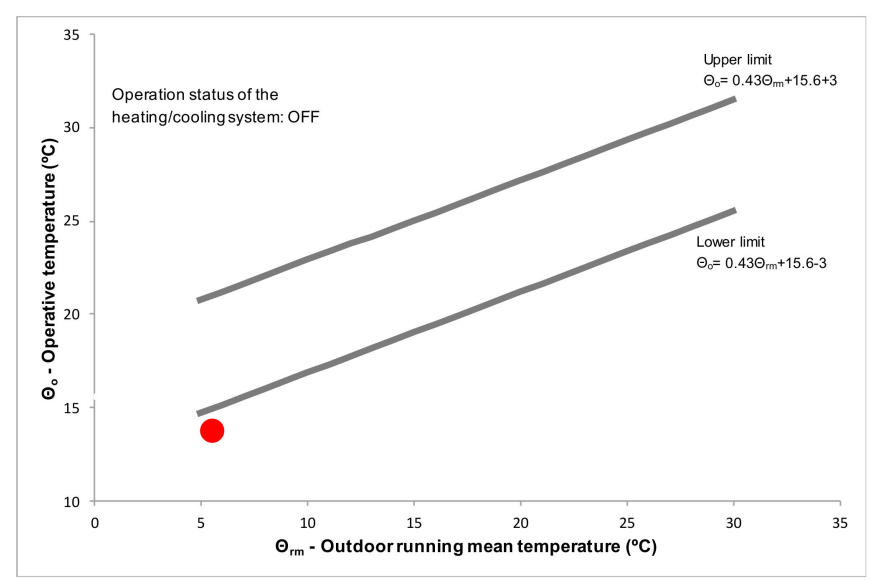

Figure 15. Adaptive comfort chart during a representative winter day. Thermal comfort temperature (operative temperature) in the bedroom/balcony.

\subsubsection{Spring}

During this monitoring campaign (carried out from 14 April to 14 May 2015), the outdoor mean air temperature was of about $16.0^{\circ} \mathrm{C}$, the maximum temperature was often below $20.0^{\circ} \mathrm{C}$, and the minimum values varied between $5.0^{\circ} \mathrm{C}$ and $10.0^{\circ} \mathrm{C}$ (Table 6 and Figure 16). The outdoor air temperatures had significative daily variations during the period, with maximum and minimum values having a slight increment in the last days of the period (Figure 16). The maximum temperature recorded was $34.2{ }^{\circ} \mathrm{C}$, while the minimum was below $4{ }^{\circ} \mathrm{C}$ (Table 6).

Table 6. Comparison between outdoor and indoor air temperatures and relative humidity values during the spring.

\begin{tabular}{cccccc}
\hline \multicolumn{7}{c}{ Spring } \\
\hline Place/Room & Outdoor & $\begin{array}{c}\text { Kitchen/Living } \\
\text { Room }\end{array}$ & Bedroom/Balcony & Bedroom & Bathroom \\
\hline \multicolumn{7}{c}{ Temperature $\left.\mathbf{~}^{\circ} \mathbf{C}\right)$} \\
Mean & 16.0 & 15.2 & 18.1 & 17.2 & 17.9 \\
Maximum & 34.2 & 19.2 & 28.9 & 24.0 & 28.7 \\
Minimum & 3.8 & 13.2 & 11.0 & 13.5 & 12.4 \\
\hline Mean & 65.9 & 70.3 & 59.6 & 67.4 & 60.4 \\
Maximum & 92.8 & 78.0 & 72.0 & 77.0 & 74.0 \\
Minimum & 11.3 & 62.0 & 46.0 & 47.0 & 43.0 \\
\hline
\end{tabular}




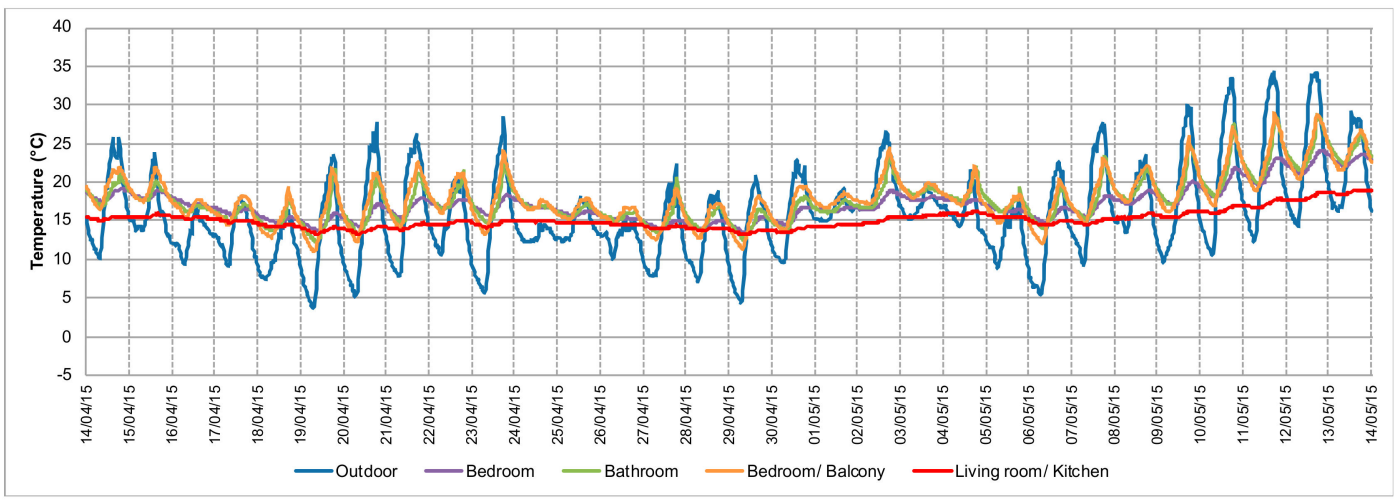

(a)

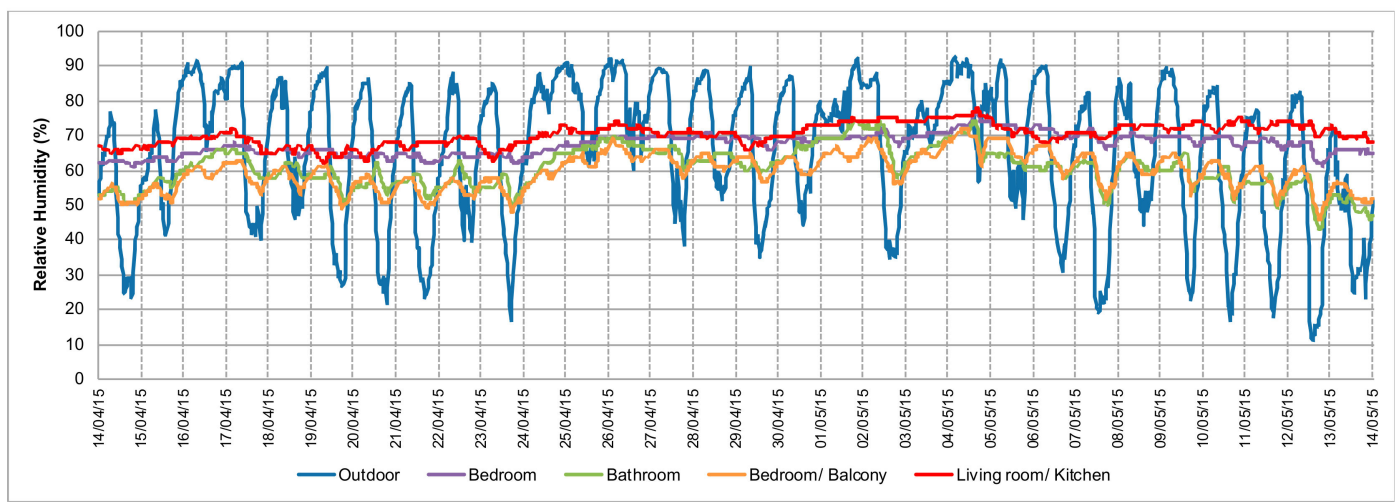

(b)

Figure 16. Spring monitoring: (a) Indoor and outdoor air temperature profiles; (b) Indoor and outdoor air relative humidity profiles.

In the spring, it was observed a relevant difference between the indoor air temperatures of the rooms located on the ground floor and those on the upper floor. Concerning the ground floor, the living room/kitchen had a very stable indoor temperature during the monitoring period, with a mean air temperature of $15.2{ }^{\circ} \mathrm{C}$ (Table 6). In the upper floor, it was observed that the indoor temperature was less stable, particularly in the rooms in the glazed balcony. The increase in the outdoor temperature and the number of hours of solar radiation had a strong influence on the temperature of these rooms. The bedroom had a more stable temperature profile, since it has fewer solar gains through the windows and higher thermal inertia due to the granite walls. The bedroom/balcony had the highest indoor temperature in the building during the monitoring period. The maximum temperature in the bedroom/balcony always remained below the outdoor temperature, since during the monitoring period, the curtains were closed. Nevertheless, from May onwards, when the outdoor temperature begins to rise, closing the curtains is the right decision to reduce solar gains. However, since the glazed area is protected by an inside shading device (opaque curtains), it is difficult to avoid overheating both in the bedroom/balcony and in the bathroom, as shown in Figure 16a).

Regarding the outdoor relative humidity, it was found that there is a high daily fluctuation, reaching values near $93 \%$ during the night and minimum values of $11.3 \%$ during the day (Table 6 ). Indoors, the values were stable, with daily variations around $10 \%$. The bedroom/balcony and the bathroom showed higher daily variation, and the mean relative humidity was of around $60 \%$ (Table 6). The relative humidity is within the recommended levels for human health and comfort [35]. The living room/kitchen and the bedroom also had a very stable relative humidity profile, with mean values around $70 \%$ (Table 6).

The thermal comfort assessment was carried out both in the bedroom/balcony and the living room/kitchen, without the heating system in operation. From the analysis of the adaptive comfort 
charts, it is possible to conclude that the thermal comfort conditions in the living room $/ \mathrm{kitchen}$ are below the lower comfort limit (Figure 17a), even with an operative temperature of $18.9^{\circ} \mathrm{C}$ and an outdoor running mean temperature above $20^{\circ} \mathrm{C}$. The low heat gains and mainly the high thermal inertia of the envelope are the main factors affecting these results. In the survey, the two occupants (1.0 met; $0.44-0.58$ clo) answered as being "slightly cool".

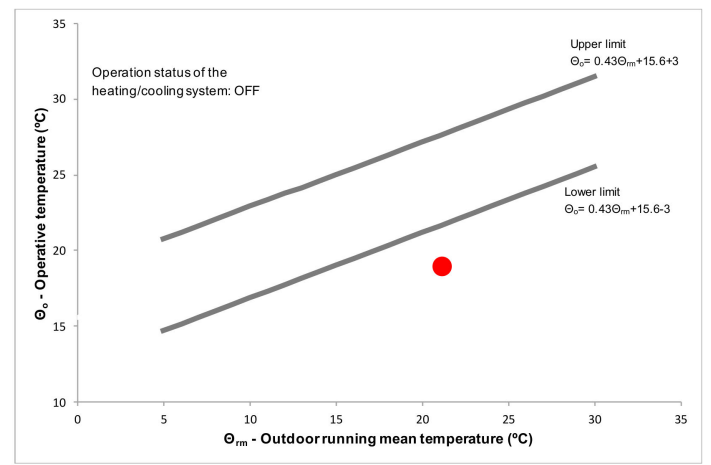

(a)

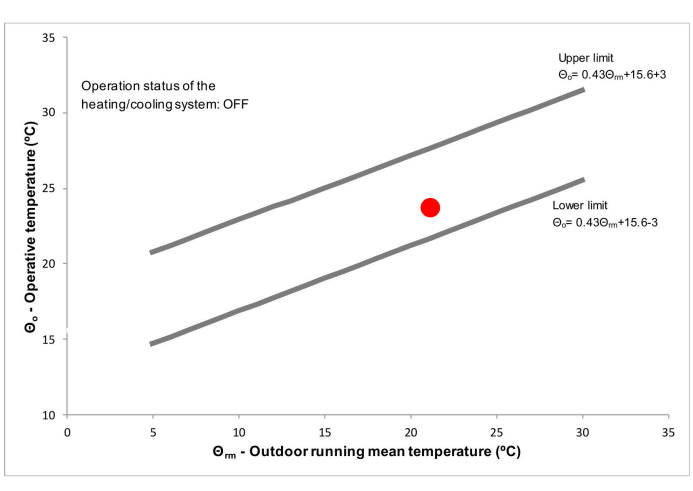

(b)

Figure 17. Adaptive comfort chart during a representative spring day: (a) Thermal comfort temperature (operative temperature) in the living room/kitchen; (b) Thermal comfort temperature (operative temperature) in the bedroom/balcony.

In contrast, the bedroom/balcony had a thermal condition within the comfort range. The operative temperature was higher than in the ground floor due to the heat gains provided by the glazed balcony. In the comfort survey, the two occupants (1.0 met; 0.44 and 0.58 clo) answered as being "neutral", which confirms the measurements.

\subsubsection{Summer}

The summer monitoring was carried out from 18 July to 18 August 2015. In this period, the mean outdoor temperature was of $24^{\circ} \mathrm{C}$, there was a high daily thermal amplitude, with several days reaching most of the time maximum values around $35.0^{\circ} \mathrm{C}$ (and a peak of $39.1^{\circ} \mathrm{C}$ ), and minimum values around $15.0^{\circ} \mathrm{C}$ (Table 7).

Table 7. Comparison between outdoor and indoor air temperatures and relative humidity values during the summer.

\begin{tabular}{cccccc}
\hline \multicolumn{7}{c}{ Summer } \\
\hline Place/Room & Outdoor & $\begin{array}{c}\text { Kitchen/Living } \\
\text { Room }\end{array}$ & Bedroom/Balcony & Bedroom & Bathroom \\
\hline \multicolumn{7}{c}{ Temperature $\left.\mathbf{~}^{\circ} \mathbf{C}\right)$} \\
Mean & 23.7 & 24.1 & 26.8 & 26.8 & 27.1 \\
Maximum & 39.1 & 26.2 & 35.0 & 31.0 & 35.2 \\
Minimum & 12.4 & 21.4 & 19.6 & 22.7 & 21.5 \\
\hline Mean & 54.1 & Relative Humidity (\%) & & \\
Maximum & 89.4 & 51.8 & 46.0 & 48.1 & 46.5 \\
Minimum & 13.8 & 63.0 & 64.0 & 60.0 & 65.0 \\
\hline
\end{tabular}

From the analysis of Figure 18, it is possible to conclude that the living room/kitchen had the most stable temperature profile, with a mean temperature of $24.1^{\circ} \mathrm{C}$ (Figure 18 and Table 7). This is due to the higher thermal inertia and lower direct solar gains of the room. As mentioned before, this room 
was initially for storage and thus, during summer, it had the advantage of keeping the temperature stable. In its current use, during summer it is the room with the best thermal comfort conditions.

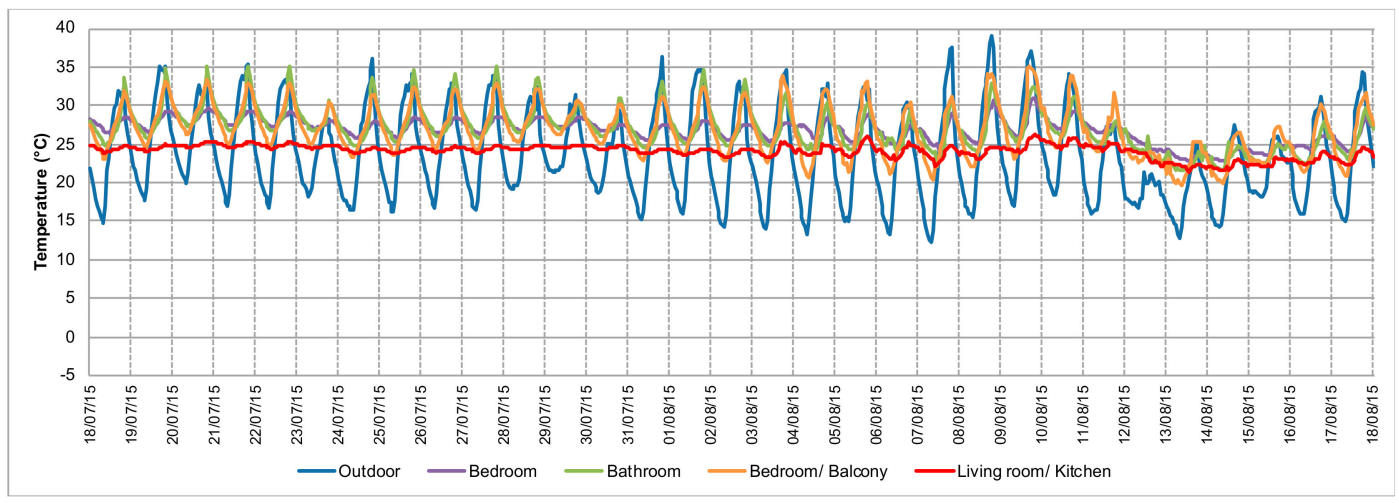

(a)

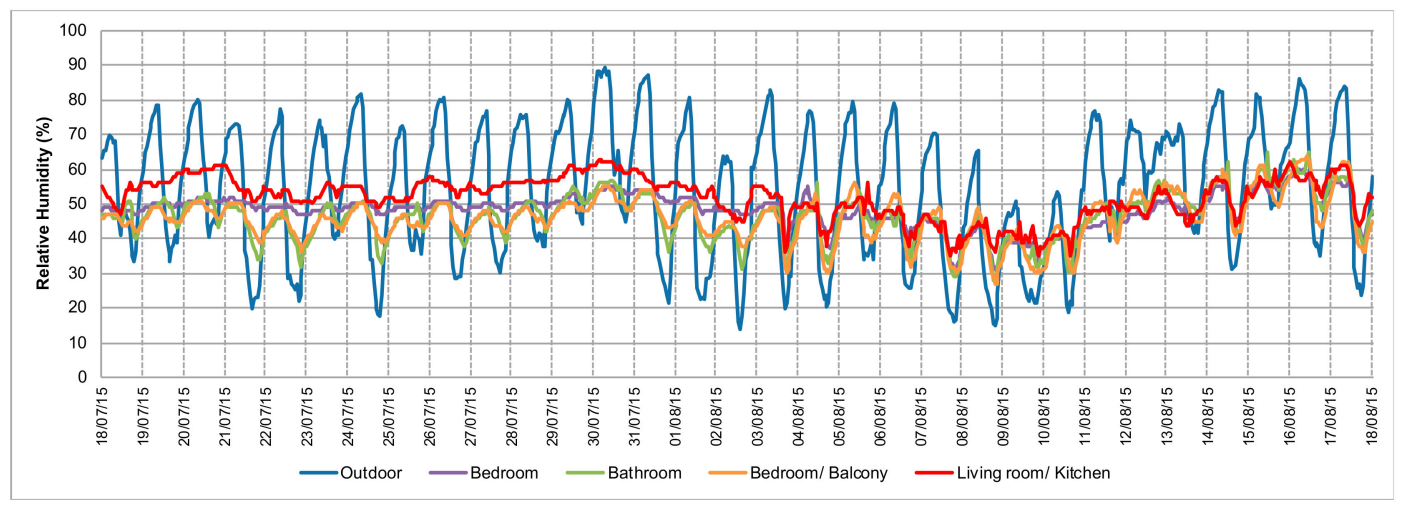

(b)

Figure 18. Summer monitoring: (a) Indoor and outdoor air temperature profiles; (b) Indoor and outdoor air relative humidity profiles.

In the upper floor, the bedroom is the room with the most stable air temperature profile with slight day to night temperature variations (usually around $3{ }^{\circ} \mathrm{C}$ ). The reason for the small differences in this room can be related to the higher thermal inertia than the other rooms in the upper floor. Nevertheless, when it was unoccupied, and therefore without ventilation, the maximum air temperature in this room was around $30^{\circ} \mathrm{C}$.

Regarding the rooms in the balcony, as in the seasons previously presented, it was observed that the indoor temperature had significant daily variations. In these rooms, indoor temperature follows the outdoor temperature profile during the day (due to both solar gains and heat losses through the glazing area). The minimum mean indoor temperature stabilizes around $25^{\circ} \mathrm{C}$, while the minimum outdoor temperature was usually $10{ }^{\circ} \mathrm{C}$ lower (Table 7 and Figure 18). The larger glazed area of these spaces, facing southwest, is the reason for these rooms having higher temperatures due to the solar gains.

In this season, the building was occupied during the entire month of August. From the moment the building began to be occupied, it was expected that the promotion of natural ventilation would change the indoor temperature profile, but this is not noticeable in the graphs (Figure 18a). The maximum temperature in the rooms remained similar (Figure 18a) since the flow of warmer air from the outdoors into the building during the day does not favor its cooling. On the other hand, during the night, the minimum temperature slightly dropped due to the ventilation since the outdoor air temperature was lower during the night. During the occupation period, the inhabitants closed the curtains during the morning to avoid solar gains (usually until 2 p.m.). However, since there are no external shading 
devices in addition to the fact that windows were kept open for ventilation, it is difficult to control the solar gains through the glazed area of the balcony.

Nonetheless, the airflow in the building can improve occupants' thermal sensation by increasing convective heat losses from their bodies. The most-recommended solutions to avoid solar gains in the cooling season are to use an external shading device and to use night ventilation to remove diurnal thermal loads. At this point, it is worth mentioning that if the balcony had its original configuration (i.e., if it was a space separated from the indoor rooms by a wall) it would influence in a very positive way the thermal behavior of the building during this season. The reasoning for this is that it would act as a buffer space between outdoor and indoor rooms and would work as a shading device of the openings that existed in the demolished wall.

Regarding the outdoor relative humidity, it showed significant daily variations, with maximum values around $70-80 \%$ and sometimes near to $90 \%$ during the night, and minimum values varying from near $40 \%$ to minimum values of $14 \%$ during the day (Table 7 ). The mean value is of around $55 \%$ (Table 7). The indoor relative humidity has lower daily variations, being relatively stable (Figure 18b). The rooms with the most stable relative humidity profiles are the living room/kitchen and the bedroom. In general, the relative humidity decreases during the day due to the warmer dry air and increases during the night due to the cooler outdoor humid air that flows into the building. This is particularly visible in the rooms with the balcony, where daily variations are higher.

The period of occupation (starting on 4 August) influenced indoor relative humidity profiles, increasing the daily humidity variation, even in rooms with stable profiles. This reduction in relative humidity values is related to the ventilation and circulation of hot air from outdoors. The relative humidity slightly raised during some rainy days and then decreased again.

In the thermal comfort assessment, the living room/kitchen and the bedroom/balcony showed a thermal environment within the comfort range (Figure 19a). The operative temperature in the living room/kitchen is more stable due to the higher thermal inertia, and therefore this room had a better thermal condition during the summer. The results of the survey confirmed the measurements, since the two occupants (1.0 met; $0.27-0.43$ clo) answered as being "neutral".

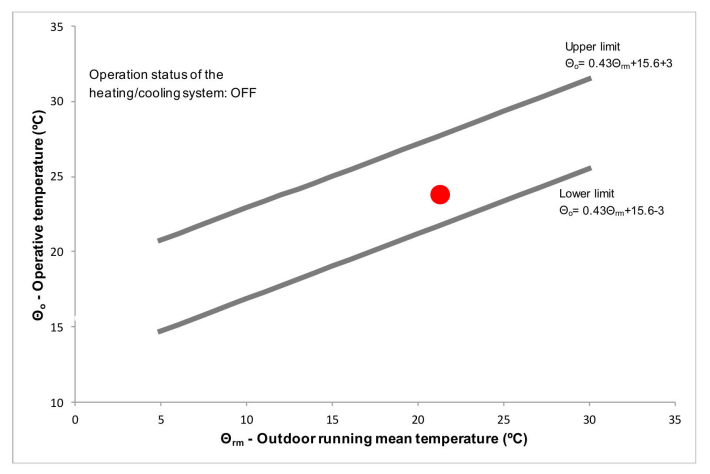

(a)

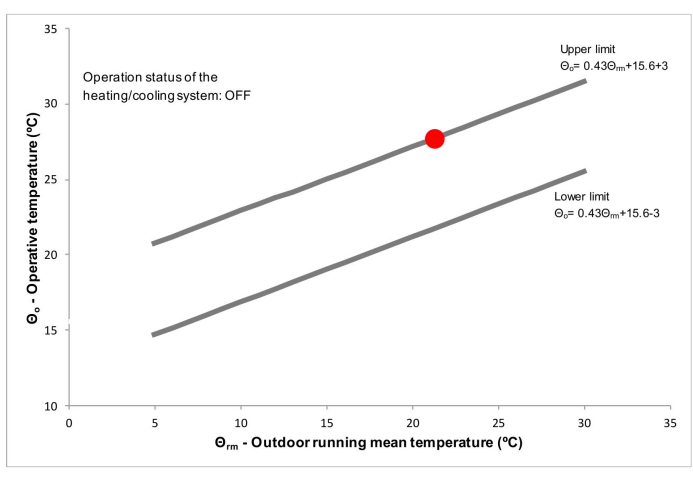

(b)

Figure 19. Adaptive comfort chart during a representative summer day: (a) Thermal comfort temperature (operative temperature) in the kitchen/living room; (b) Thermal comfort temperature (operative temperature) in the bedroom/balcony.

In the bedroom/balcony, the operative temperature was close to the upper comfort limit, mainly due to the solar gains through the glazed envelope (Figure 19b). In the survey, one occupant (1.0 met; $0.43 \mathrm{clo})$ answered as being "slightly warm" and the other (1.0 met; $0.27 \mathrm{clo})$ as being "neutral". The difference between the answers is mainly related to different clothing insulation levels. 


\subsection{Indoor Air Quality Monitoring}

\subsubsection{Carbon Dioxide Concentration}

In this section, the carbon dioxide $\left(\mathrm{CO}_{2}\right)$ concentration in the case study is evaluated and classified according to the categories defined by EN 15251 [35]. The $\mathrm{CO}_{2}$ concentrations were measured in different rooms during a representative day of each season. During the winter, the measurements were carried out in two situations, i.e., with and without the closed wood-burning fireplace in operation, to verify the influence of the fireplace use in the $\mathrm{CO}_{2}$ concentrations. From the measurements, it was verified that the use of the fireplace slightly increased the $\mathrm{CO}_{2}$ concentrations, but they did not exceed the design values for category I (high level of expectation) (Table 8). The small differences between outdoor and indoor carbon dioxide concentrations are due to the low occupation density of the building, to the natural ventilation and infiltration rate, and to the efficiency of the closed fireplace exhaust system. In the records, two values correspond to category III. A possible explanation for this situation is that those two rooms were closed until the beginning of the measurements, and therefore the $\mathrm{CO}_{2}$ concentrations were higher. Although the case study is an old building, the results showed that the $\mathrm{CO}_{2}$ concentrations are, most of the time, within the boundaries of the most demanding category.

Table 8. Classification of indoor air quality in representative rooms.

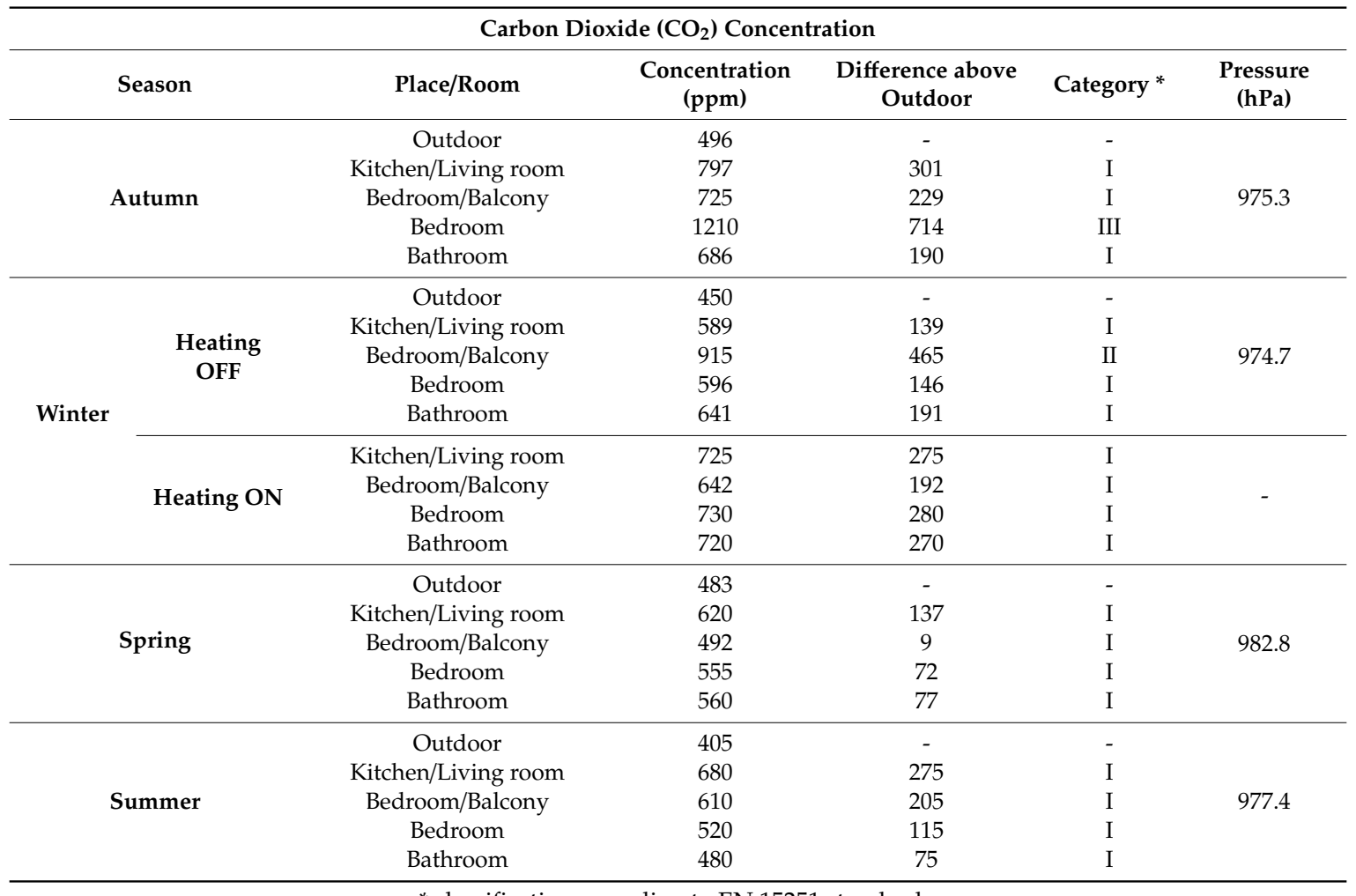

* classification according to EN 15251 standard.

\subsubsection{Radon Gas Concentration}

The concentration of carbon dioxide is a good indicator of air quality in buildings where occupants are the main source of pollution. However, since the building is located on a granitic area, it is also necessary to measure the radon gas concentration [42]. Radon-without color, odor, or taste-results from the decay of the radium and is found in rocks and soils, as in the granitic massif where the building is located. Its infiltration in buildings generally takes place through the foundations. The high concentration of radon in the environment has health risks, since the element is lodged in the lungs by inhalation and its main effect is the lung cancer (risk potential increases in about $16 \%$ for each $100 \mathrm{~Bq} / \mathrm{m}^{3}$ in long-term average radon concentration) [43]. According to the World Health Organization 
(WHO), radon is the second leading cause of lung cancer, after smoking in smokers, and the first among those who have never smoked [43]. Directive 2013/59/EURATOM [44] states that the reference level for the annual average concentration of activity in the air should not exceed $300 \mathrm{~Bq} / \mathrm{m}^{3}$ per year in new construction homes and workplaces, whose approximate equivalence is $10 \mathrm{mSV}$ annual, according to recent calculations by the International Radiological Protection Community [44]. In the Portuguese context, and according to national legislation [42], it is mandatory to study and measure the concentrations of radon in granitic sites, as the one where the case study is located.

In the case study, the concentration of radon was measured during the heating season, when the ventilation rate was lower. The living room/kitchen was the room chosen for the measurements since it has the lower ventilation rates, has granite walls, is located in the ground floor, and it sits on a granitic massif. The measurements took place during 28 days, with integration periods of 10 min, started after a period of stabilisation of the radon sensor (about 60 days). Figure 20 shows the results of the measurements. It is possible to see an irregular distribution of values with several peaks. The peaks in the radon concentration are considerably above the maximum defined by the Portuguese law $\left(400 \mathrm{~Bq} / \mathrm{m}^{3}\right)$ [42], with a maximum of $2660 \mathrm{~Bq} / \mathrm{m}^{3}$, and an average concentration of $1432 \mathrm{~Bq} / \mathrm{m}^{3}$. Although the concentration of radon was high, it has to be taken into consideration that the building was unoccupied most of the time and thus had low ventilation rates.

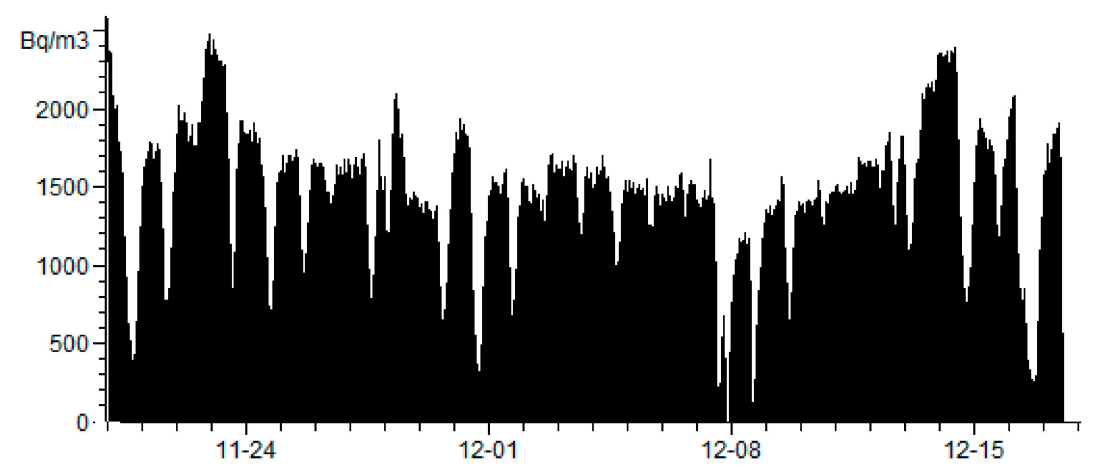

Figure 20. Concentrations of radon in the living room/kitchen during the winter period.

During a short period of occupation, 7 and 8 December, even with low ventilation rates (windows and doors were only open sporadically), as it was winter, the concentration of radon sharply fell to values below $300 \mathrm{~Bq} / \mathrm{m}^{3}$, as recommend by the Directive 2013/59/EURATOM [44]. Although the air change rate of the case study building was not measured, results show that the way the occupants use the building is sufficient to maintain the radon concentrations within the mandatory values. Therefore, ventilation must not be neglected in this type of buildings, particularly after renovations when the airtightness of the envelope increases due to the replacement of windows and doors, and no other measures are implemented to mitigate the ingress of radon into the building. In buildings located in granitic areas, it is necessary to maintain a minimum hourly air change rate to remove radon or to renovate the ground floor, by introducing, for example, a waterproofing membrane that does not allow the flux of radon gas from the ground to the indoor environment. In the renovation of this case study, measures to prevent the ingress of radon gas into the building were not introduced and therefore ventilation is the only way to control the radon gas concentration.

\subsection{Conditions and Limitations of the Study}

The outcomes of this study are based on the analysis of the annual thermal behavior of just one case study, since in this region of Portugal it was not possible to identify other case studies in good conservation conditions or that are still occupied. Nevertheless, this building is representative of the typical glazed balcony vernacular buildings of Northern Portugal and Spain, and has the typical functional organization of this type of house, with the ground floor used to store goods and/or livestock 
(coldest part of the building) and the occupied area on the first floor (part of the house with higher solar gains and comfort levels). In the case study building, the glazed balcony is the focus of the study, and it is representative of this type of architecture, due to its size and orientation. Additionally, the case study was refurbished and therefore presented good conditions to carry out the research.

Since it was the only case study available to evaluate, it was not possible to statistically analyze and compare the behavior of this building with similar ones in the same region.

The results presented are specific to this zone due to the particular type of climate. Nonetheless, the benefits of the glazed balconies can be extrapolated to other areas with similar climates and not only to buildings with similar characteristics.

Another limitation of this study is the fact that the building is a vacation house that is only used during weekends and holidays. Since this building is mainly used for short periods, especially during winter, it is possible that some of the inhabitants' potential actions to improve the indoor environmental quality were not fully addressed.

\section{Conclusions}

The results of the research work presented showed the viability of using glazed balconies as a passive heating strategy in a climate with cold winters. This type of building is common in the North of Portugal, in the North of Spain, and in other regions where passive principles (as the glazed balcony) are implemented in buildings to increase solar gains during the heating season.

The glazed balconies act as a sunspace, increasing the contribution of solar gains in the maintenance of the thermal comfort conditions during the heating season. In Portuguese vernacular architecture, these elements are normally well oriented, and there is a proportional relationship between their dimensions and the ones of the adjacent rooms. Glazed balconies are always on the upper floors, for better sun exposure, and are adjacent to living spaces (usually living rooms and bedrooms).

During occupation period of the mid-seasons, the rooms in the balcony had adequate comfort conditions, since the occupants can easily control the solar gains using the shading system (opaque curtains). Not controlling the solar radiation increases the risk of overheating periods, as seen during autumn (when the building was not occupied).

In winter, the results showed that it is difficult to achieve adequate thermal comfort conditions without an active heating system. Nevertheless, during the thermal comfort assessment, performed on a cloudy day, the operative temperature was close to the lower limit of the thermal comfort range. Even when the building was in free-running mode, that was the case for most of the monitoring period, during sunny days and even with the solar shading active, it was possible to verify that the indoor air temperature increases considerably.

During summer, the results showed that the thermal comfort conditions are within the comfort limits, but with some risk of overheating. The use of an external solar shading device will be more effective to reduce the risk of excessive solar gains and overheating during summer than the existing curtains.

From the results presented, it was possible to compare periods with and without occupation, which highlights the importance of the occupants' actions in optimising the solar gains through the glazed balcony and, therefore, regulate their comfort conditions by activating/deactivating solar shading and promoting natural ventilation (useful to remove air pollutants and heat loads-particularly during night-time).

Since the glazed balcony is the main passive strategy in this building, it is important to note that by removing the partition wall between the glazed balcony and the other rooms, the original buffer zone was eliminated. The removed tabique wall thermal inertia was also useful, both in winter and summer, to keep the indoor temperature more stable. The balcony would also act as a sunspace in winter, increasing the solar heat gains, and as a buffer space, reducing heat losses. In summer, with the windows open, the glazed balcony will work as a shading device for the building walls. 
The floor area of this kind of building is small for current living standards and therefore, during refurbishment operations, the partition walls between the rooms and the glazed balcony were removed to increase the net floor area. Additionally, the traditional materials were replaced by modern industrial materials (e.g., aluminium, steel, and plasterboard). The lack of knowledge on the advantages of using this passive strategy is resulting in the destruction of this vernacular technique that is one of the architectonic identities of Northern Portugal vernacular architecture. Hence, during the renovation of this type of building, it is necessary to take into account the balance between the functional needs of the spaces and the effectiveness of existing passive strategies in order to harmonize them.

Additionally, further studies are needed to complement and corroborate the research presented, to understand better the effectiveness of this strategy, and to disseminate its advantages on improving thermal comfort conditions and reducing the energy needs for heating. Moreover, it is necessary to promote its use in new buildings, since the benefits have also already been discussed in other studies.

Regarding indoor air quality, even after a renovation where the airtightness of the envelope was improved, the concentrations of carbon dioxide in the building did not exceed the most demanding design values for new buildings, according to EN 15251, even when the closed wood-burning fireplace was in operation. The measurements of the radon gas concentrations conducted during a long period without occupation showed average values above the maximum defined by national legislation. During the occupation period and even with low ventilation rates, the radon gas concentration rapidly decreased to acceptable values, thus not harming the occupants' health. Nevertheless, the need to maintain a minimum hourly air change rate to remove air pollutants and assure a healthy indoor environment must be emphasized.

Author Contributions: J.F. undertook the main part of the research that was the base of this article. He developed the research method and analyzed the results with the contribution of R.M. (Raphaele Malheiro) and M.d.F.C., who wrote the document with the input of S.M.S. and R.M. (Ricardo Mateus). S.M.S. and R.M. (Ricardo Mateus) helped to develop the discussion sections of the paper and provided critical judgment on the undertaken research. Additionally, they supervised all the works and revised the document. H.G. helped in the preparation of the article. All authors have read and agreed to the published version of the manuscript.

Funding: The authors would like to acknowledge the support granted by the FEDER funds through the Competitively and Internationalization Operational Programme (POCI) and by national funds through FCT (Foundation for Science and Technology) within the scope of the project with the reference POCI-01-0145-FEDER-029328, and of the Ph.D. grant with the reference PD/BD/113641/2015, that were fundamental for the development of this study.

Acknowledgments: The authors also wish to thank José Pombo and his family, and Tabuaço's Municipality for helping this research work.

Conflicts of Interest: The authors declare no conflict of interest. The funders had no role in the design of the study; in the collection, analyses, or interpretation of data; in the writing of the manuscript, or in the decision to publish the results.

\section{References}

1. EEA Directive 2012/27/EU of the European Parliament and of the Council of 25 October 2012 on Energy Efficiency, Amending Directives 2009/125/EC and 2010/30/EU and Repealing Directives 2004/8/EC and 2006/32/EC. 2012. Available online: https:/eur-lex.europa.eu/LexUriServ/LexUriServ.do?uri=OJ:L:2012:315: 0001:0056:en:PDF (accessed on 27 January 2020).

2. European Council. EUCO 169/14-2030 Climate and Energy Policy Framework and Economic Issues; European Council: Brussels, Belgium, 2014.

3. EEA Directive (EU) 2018/844 of the European Parliament and of the Council of 30 May 2018 Amending Directive 2010/31/EU on the Energy Performance of Buildings and Directive 2012/27/EU on Energy Efficiency. 2018. Available online: https://eur-lex.europa.eu/legal-content/EN/TXT/PDF/?uri=CELEX:32018L0844\& from=EN (accessed on 27 January 2020).

4. Abalos, I. Harvard Design Magazine 30: (Sustainability) + Pleasure, Vol. 1.; Harvard University: Cambridge, MA, USA, 2009; pp. 14-17. 
5. Li, J.; Colombier, M. Managing carbon emissions in China through building energy efficiency. J. Environ. Manag. 2009, 90, 2436-2447. [CrossRef] [PubMed]

6. Passer, A.; Kreiner, H.; Maydl, P. Assessment of the environmental performance of buildings: A critical evaluation of the influence of technical building equipment on residential buildings. Int. J. Life Cycle Assess. 2012, 17, 1116-1130. [CrossRef]

7. Cardinale, N.; Rospi, G.; Stefanizzi, P. Energy and microclimatic performance of Mediterranean vernacular buildings: The Sassi district of Matera and the Trulli district of Alberobello. Build. Environ. 2013, 59, 590-598. [CrossRef]

8. Kimura, K. Vernacular technologies applied to modern architecture. Renew. Energy 1994, 5, 900-907. [CrossRef]

9. Gallo, C. Bioclimatic architecture. Renew. Energy 1994, 5, 1021-1027. [CrossRef]

10. Coch, H. Chapter 4-Bioclimatism in vernacular architecture. Renew. Sustain. Energy Rev. 1998, 2, 67-87. [CrossRef]

11. Cañas, I.; Martín, S. Recovery of Spanish vernacular construction as a model of bioclimatic architecture. Build. Environ. 2004, 39, 1477-1495. [CrossRef]

12. Singh, M.K.; Mahapatra, S.; Atreya, S.K. Solar passive features in vernacular architecture of North-East India. Sol. Energy 2011, 85, 2011-2022. [CrossRef]

13. ICOMOS. Charter on the Built Vernacular Heritage. Mexico. 1999. Available online: https://www.icomos.org/ charters/vernacular_e.pdf (accessed on 27 January 2020).

14. Oliveira, E.V.; Galhano, F. Arquitectura Tradicional Portuguesa; Publicações Dom Quixote: Lisboa, Portugal, 1992.

15. Sayigh, A.; Marafia, A.H. Chapter 2-Vernacular and contemporary buildings in Qatar. Renew. Sustain. Energy Rev. 1998, 2, 25-37. [CrossRef]

16. Martín, S.; Mazarrón, F.R.; Cañas, I. Study of thermal environment inside rural houses of Navapalos (Spain): The advantages of reuse buildings of high thermal inertia. Constr. Build. Mater. 2010, 24, 666-676. [CrossRef]

17. Singh, M.K.; Mahapatra, S.; Atreya, S.K. Thermal performance study and evaluation of comfort temperatures in vernacular buildings of North-East India. Build. Environ. 2010, 45, 320-329. [CrossRef]

18. Dili, A.S.; Naseer, M.A.; Varghese, T.Z. Passive environment control system of Kerala vernacular residential architecture for a comfortable indoor environment: A qualitative and quantitative analyses. Energy Build. 2010, 42, 917-927. [CrossRef]

19. Shanthi Priya, R.; Sundarraja, M.C.; Radhakrishnan, S.; Vijayalakshmi, L. Solar passive techniques in the vernacular buildings of coastal regions in Nagapattinam, TamilNadu-India-A qualitative and quantitative analysis. Energy Build. 2012, 49, 50-61. [CrossRef]

20. Singh, M.K.; Mahapatra, S.; Atreya, S.K. Bioclimatism and vernacular architecture of north-east India. Build. Environ. 2009, 44, 878-888. [CrossRef]

21. Barbosa, J.A.; Bragança, L.; Mateus, R. Assessment of land use efficiency using BSA tools: Development of a new index. J. Urban Plan. Dev. 2015, 141, 04014020. [CrossRef]

22. Ascione, F.; Bianco, N.; De Rossi, F.; De Masi, R.F.; Vanoli, G.P. Concept, Design and Energy Performance of a Net Zero-Energy Building in Mediterranean Climate. Procedia Eng. 2016, 169, 26-37. [CrossRef]

23. Asdrubali, F.; Cotana, F.; Messineo, A. On the Evaluation of Solar Greenhouse Efficiency in Building Simulation during the Heating Period. Energies 2012, 5, 1864-1880. [CrossRef]

24. Küess, H.; Koller, M.; Hammerer, T. Detail Green-English Edition; Institut für Internationale Architektur-Dokumentation GmbH \& Co.: Munich, Germany, 2011; pp. 44-49.

25. Costa Carrapiço, I.; Neila-González, J. Study for the rehabilitation of vernacular architecture with sustainable criteria. In Proceedings of the Vernacular Heritage and Earthen Architecture: Contributions for Sustainable Development; Correia, M., Carlos, G., Rocha, S., Eds.; CRC Press/Balkema: Vila Nova da Cerveira, Portugal, 2013; pp. 581-586.

26. Fernandes, J.; Mateus, R.; Bragança, L.; Correia da Silva, J.J. Portuguese vernacular architecture: The contribution of vernacular materials and design approaches for sustainable construction. Archit. Sci. Rev. 2015, 58, 324-336. [CrossRef]

27. Fernandes, J.; Pimenta, C.; Mateus, R.; Silva, S.M.; Bragança, L. Contribution of Portuguese Vernacular Building Strategies to Indoor Thermal Comfort and Occupants' Perception. Buildings 2015, 5, 1242-1264. [CrossRef] 
28. Fernandes, J.; Mateus, R.; Gervásio, H.; Silva, S.M.; Bragança, L. Passive strategies used in Southern Portugal vernacular rammed earth buildings and their influence in thermal performance. Renew. Energy 2019, 142, 345-363. [CrossRef]

29. AAVV. Arquitectura Popular em Portugal, 3rd ed.; Associação dos Arquitectos Portugueses: Lisboa, Portugal, 1988.

30. International Organization for Standardization. ISO7726. In Ergonomics of the Thermal Environment E Instruments for Measuring Physical Quantities; ISO: Geneva, Switzerland, 2002.

31. International Organization for Standardization. ISO7730. In Ergonomics of the Thermal Environment: Analytical Determination and Interpretation of Thermal Comfort Using Calculation of the Pmv and Ppd Indices and Local Thermal Comfort Criteria; ISO: Geneva, Switzerland, 2005.

32. ASHRAE. ASHRAE 55-Thermal Environmental Conditions for Human Occupancy. In ANSI/ASHRAE Stand. 55; ASHRAE: Atlanta, GA, USA, 2013.

33. Matias, L. TPI65-Desenvolvimento de um Modelo Adaptativo Para Definição das Condições de Conforto Térmico em Portugal; Laboratório Nacional de Engenharia Civil/National Laboratory of Civil Engineering: Lisboa, Portugal, 2010; ISBN 978-972-49-2207-2.

34. ASHRAE. ANSI/ASHRAE Standard 55-Thermal Environmental Conditions for Human Occupancy; ASHRAE: Atlanta, GA, USA, 2004.

35. EN15251. Indoor Environmental Input Parameters for Design and Assessment of Energy Performance of BuildingsAddressing Indoor Air Quality, Thermal Environment, Lighting and Acoustics; BSI: London, UK, 2007.

36. Monteiro, J.G. Tabuaço: Esboços e Subsídios Para Uma Monografia; Câmara Municipal de Tabuaço: Tabuaço, Portugal, 1991.

37. SNIAmb. Soil Map of-Environment Atlas-SNIAmb—Agência Portuguesa do Ambiente. Available online: https://sniamb.apambiente.pt/content/geo-visualizador?language=pt-pt (accessed on 14 June 2018).

38. LNEG. Geological Map of Portugal at 1:1 000 000—Geoportal do Laboratório Nacional de Energia e Geologia. Available online: http://geoportal.lneg.pt/geoportal/mapas/index.html (accessed on 14 June 2018).

39. Agencia Estatal de Meteorología. Atlas Climático Ibérico: Temperatura do Ar e Precipitação (1971-2000)/Iberian Climate Atlas: Air Temperature and Precipitation (1971/2000); Agencia Estatal de Meteorología, Ministerio de Medio Ambiente y Medio Rural y Marino, Instituto de Meteorologia de Portugal: Madrid, Spain, 2011; ISBN 978-84-7837-079-5.

40. Pina dos Santos, C.A.; Rodrigues, R. ITE54-Coeficientes de Transmissão Térmica de Elementos Opacos da Envolvente dos Edificios; Laboratório Nacional de Engenharia Civil/National Laboratory of Civil Engineering: Lisboa, Portugal, 2009; ISBN 978-972-49-2180-8.

41. Pina dos Santos, C.A.; Matias, L. ITE50-Coeficientes de Transmissão Térmica de Elementos da Envolvente dos Edificios; Laboratório Nacional de Engenharia Civil/National Laboratory of Civil Engineering: Lisboa, Portugal, 2006.

42. Diário da República. Regulamento de Desempenho Energético dos Edifícios de Comércio e Serviços (RECS)—Requisitos de Ventilação e Qualidade do Ar Interior. 2013. Available online: https://dre.pt/ application/conteudo/331868 (accessed on 27 January 2020).

43. Ting, D.S. WHO Handbook on Indoor Radon: A Public Health Perspective. Int. J. Environ. Stud. 2010, 67, 100-102. [CrossRef]

44. EEA Council Directive 2013/59/Euratom of 5 December 2013 Laying Down Basic Safety Standards for Protection against the Dangers Arising from Exposure to Ionising Radiation, and Repealing Directives 89/618/Euratom, 90/641/Euratom, 96/29/Euratom, 97/43/Euratom a. 2013. Available online: https://eur-lex. europa.eu/LexUriServ/LexUriServ.do?uri=OJ:L:2014:013:0001:0073:EN:PDF (accessed on 27 January 2020).

(C) 2020 by the authors. Licensee MDPI, Basel, Switzerland. This article is an open access article distributed under the terms and conditions of the Creative Commons Attribution (CC BY) license (http://creativecommons.org/licenses/by/4.0/). 